\title{
Kahramanmaraş Kent Merkezinde Balık Eti Tüketim Analizi*
}

\author{
Oğuzhan ERCAN, Ahmet ŞAHIN \\ KSÜ, Ziraat Fakültesi, Tarım Ekonomisi Bölümü, Kahramanmaraş
}

Geliş (Received): 17.12.2015

Kabul (Accepted): 29.02.2016

\begin{abstract}
ÖZET: Sağlıklı ve dengeli beslenmenin en önemli koşullarından biri, insan vücudunun ihtiyacı olan proteini dengeli bir şekilde almakla mümkündür. Bu bakımdan, zengin protein içeriği ve yapısında bulunan çoklu doymamış yağ asitleri yönünden zengin olan balık eti, hayvansal protein kaynağı olarak insan sağlı̆̆ için vazgeçilmez bir öneme sahiptir. Son yıllarda balık eti tüketimini arttırmaya yönelik çabaların yanında, tüketim alışkanlıklarının da belirlenmesi sağlıklı beslenme adına önemli görülmektedir. Bu çalışmanın amacı, Kahramanmaraş kent merkezinde balık eti tüketim tercihleri, tüketim şekilleri ve tüketici kararlarını etkileyen faktörlerin belirlenmesidir. Bu amaçla farklı sosyo-ekonomik gruplardaki 384 kişiden 2014 Eylül ve Ekim aylarında anket yoluyla veriler elde edilmiştir. Veriler tanımlayıcı istatistikler, çoklu doğrusal regresyon ve lojistik regresyon modellerinden yararlanılarak analiz edilmiştir. Analiz sonuçlarına göre, tüketicilerin \%84,6'sının balık tükettikleri tespit edilmiştir. Bireyin ortalama balık eti tüketim miktarı $0,344 \mathrm{~kg} /$ ay ve aylık gıda harcaması içindeki balık eti harcama miktarının oranı ise \%1,5 olarak tespit edilmiştir. Bireyin balık eti talebi için fiyat esnekliği $-1,00$, gelir esnekliği ise 0,57 olarak hesaplanmıştır. Erkeklerin balık tüketme olasılığının kadınlara göre 5,06 kat daha fazla olduğu tespit edilmiştir.
\end{abstract}

Anahtar Kelimeler: Kahramanmaraş, Balık eti tüketimi, Gelir esnekliği, Lojistik regresyon

\section{Analysis of Fish Meat Consumption at Kahramanmaraş City Centre}

ABSTRACT: One of the important conditions about healthy and well-balanced nutrition is possible by taking the protein that human body needs balanced. In this respect, fish meat, which has rich protein content and is rich of built-in poly-unsaturated fatty acids, is essential for human health as an animal protein source. In recent years, efforts to increase fish meat consumption along with determining consumption habits are seen important in the name of healthy nutrition. The purpose of this study is to determine choices of fish meat consumption at Kahramanmaraş City Centre, consumption ways and factors that affect consumption decisions. For this purpose, data obtained via survey from 384 persons in different socio-economic groups. Data were analyzed by making use of descriptive statistics, multi-linear regression and logistic regression. According to analysis results, it is confirmed that $84.6 \%$ of the consumers consume fish. It is also found that the average of an individual's fish meat consumption amount is $0.344 \mathrm{~kg} / \mathrm{month}$ and the rate of fish meat expense in monthly food spending is $1.5 \%$. Price elasticity of demand for fish meat -1.00 individual is calculated as the income elasticity of 0.57 . It is confirmed that men's fish consumption possibility is 5.06 times more than women.

Key Words: Kahramanmaraş, Fish meat consumption, Income elasticity, Logistic regression

\section{GíRiș}

Günümüzde ülkelerin gelişmişliği, kalkınma düzeyleri ve hayat standartlarının belirlenmesinde nüfusun beslenme davranışlarının yanı sıra kişi başına düşen hayvansal protein tüketim miktarları önemli bir ölçüt olarak kabul görmektedir (Yücel, 2001). Ancak son yıllarda hızla artan ülke nüfusları, insan beslenmesinde önemli yeri olan hayvansal kökenli protein kaynaklarının yetersiz kalmasına neden olmaktadır. Bu protein açığını en iyi derecede ve ucuz bir şekilde gidermede yararlanılacak kaynakların başında ise gün geçtikçe daha çok önemi anlaşılan su ürünleri gelmektedir (Angiş, 2004).

Dünya Sağlık Örgütü (WHO) verilerine göre, sağlıklı bir insanın vücut ağırlığının her kilogramı için günde 1 gr protein tüketmesi ve bunun da \%42' sinin hayvansal kökenli olması gerektiği belirtilmiştir. Gelişmiş ülkelerde, gelişmekte olan ülkelere göre kişi başına günlük protein tüketim miktarı iki kat artarken, proteinlerin hayvansal kökenli ürünlerden karşılanma oranları gelişmekte olan ülkelerde $\% 20$ civarında iken, bu oran gelişmiş ülkelerde $\% 65$ 'lere kadar çıkmaktadır (Anonim, 2013).

Dünyada kişi başı yıllık ortalama balık tüketimi $14,22 \mathrm{~kg}$, Fransa'da 22,52 kg, Yunanistan'da 13,91 kg, İran'da $8 \mathrm{~kg}$ ve İsrail'de ise $19,51 \mathrm{~kg}$ iken Türkiye'de kişi başı yıllık ortalama balık tüketimi $6,77 \mathrm{~kg}$. olup dünya ortalamasının oldukça altındadır (Anonim, 2014). Türkiye'de su ürünleri tüketim miktarı bakımından bölgeler arasında da oldukça fark vardır. Türkiye'de yılda kişi başına ortalama balık tüketiminin Doğu Anadolu, Güneydoğu Anadolu ve İç Anadolu bölgelerinde düşükken, Karadeniz ve diğer kıyı bölgelerinde ise oldukça yüksektir. Üç tarafı denizlerle çevrili olan Türkiye'nin protein ihtiyacını karşılayabileceği zengin balık kaynakları olmasına rağmen, halkın balık tüketim alışkanlığı yaygın

*KSU BAP Proje No:2014/ 2-24 YLS tarafından desteklenmiş yüksek lisans tezinden alıntıdır.

Sorumlu yazar: Şahin, A., ahmet.sahin@ksu.edu.tr 
olmadığı için ülke bu kaynaklarından yeterince faydalanamamaktadır (Dağtekin ve Ak, 2007).

2014 y1lında Türkiye'deki toplam su ürünleri üretimi 537.345 ton olup, yaklaşık \%50'si deniz ürünlerinden, $\% 44$ 'ü yetiştiricilik ürünleri ve $\% 7$ 'si tatlı su ürünlerinden elde edilmiştir. Deniz balıklarının türleri arasında hamsi en yüksek avlanan balık türü olarak görülmektedir. $\mathrm{Bu}$ üretim, avlanan deniz balıklarının $\% 42$ ' sini oluşturmaktadır. Kültür balıklarında ise en yüksek yetiştiriciliği yapılan balık alabalık olmuştur. Bu üretim toplam su ürünleri yetiştiriciliğinin \%46 'sını oluşturmaktadır (Anonim, 2014a).

Hızla artan nüfusa, ekonomik ve sosyal gelişmelere bağlı olarak beslenme anlayışı ve alışkanlıkları da hızlı bir değişim göstermektedir. $\mathrm{Bu}$ değişim tüm et türlerinde olduğu gibi balık eti tercihi ve tüketimini etkileyen faktörleri de zamanla değiştirmektedir (Cankurt ve ark., 2010). Bu bağlamda özellikle et tüketimine yönelik çalışmaların güncel tutulması önemli olacağını vurgulamıştır. Balık eti tüketiminin öneminin kavrandığı son yıllarda Dünyada ve Türkiye'de konu ile alakalı çok sayıda çalışma yapılmıştır. Kahramanmaraş'ta ise balık tüketimine yönelik araştırma az olmakla birlikte konunun regresyon yöntemleriyle yapılmış bir çalışma bulunmamaktadır. Araştırma bulgularının bu açıdan önemli olacağı düşünülmektedir. Konuyla ilgili yerli ve yabancı çalışmalarda tespit edilen bazı önemli bulgular şu şekilde sıralanmıştır.

Beyazbayrak (2014) Kahramanmaraş’ta yaptığı çalışmasında yıllık kişi başı balık tüketiminin yaklaşık 6 $\mathrm{kg}$ olduğunu tespit etmiştir. En çok tüketilen balık türü ise $(\% 40)$ alabalık ve hamsi $(\% 19,5)$ olmuştur. Temel, (2014) çalışmasında Rize ilinde kişi başına balık tüketimini 20,07 kg/yıl olarak hesaplamıştır. Aynı çalışmada sonbahar ve kış aylarında en çok barbun, sonrasında hamsi; ilkbahar ve yazın ise alabalık ve istavrit tercih edildiğini tespit etmiştir. Olgunoğlu ve ark. (2014) çalışmalarında Adıyaman ilinde kişi başı balık tüketimini 3,01 kg/yıl olarak tespit etmişlerdir. balık eti tüketenlerin öncelikli tercihlerinin (\%70) tatl su türlerinden yana olduğu, bu türler içerisinde ise en fazla sazan daha sonra alabalık tercih edildiği; deniz balıkları içerisinde ise hamsinin ilk sırada yer aldığ tespit edilmiştir. Wang ve ark. (2009) Çin'in başkenti Pekin de yaptıkları çalışmalarında tüketicilerin balığın besin içeriği ve faydasını öğrendikten sonra son yıllarda balık ve balık ürünleri tüketiminin dünyada önemli ölçüde artış gösterdiğini belirtmişlerdir. Adıgüzel ve ark. (2009) Tokat Almus'ta yaptıkları çalışmalarında kişi başına balık tüketim miktarını $14.71 \mathrm{~kg} / \mathrm{y}$ l olarak hesaplamışlardır. Akbay (2005) Kahramanmaraş kent merkezinde yaptığı çalışmasında, balık için gelir esnekliğini 0,412 olarak hesaplamıştır. Verbeke ve ark. (2004) Belçika'nın 8 bölgesinde yaptıkları çalışmalarında, balığın bilimsel kanıtlarında gösterdiği gibi kroner kalp hastalığı riskini azalttığını bu nedenle toplumda sağlıklı bir yiyecek olarak algılandığını ve bu algılamanın bayanlarda erkeklere göre daha fazla olduğunu belirlemişlerdir. Paksoy (1998) Kahramanmaraş'ta yaptığı çalışmasında, balık eti talebi için gelir esnekliğini 0,97 olarak hesaplamıştır.

Türkiye, geçmiş yıllarda kırmız ette deli dana krizini, tavuk etinde ise kuş gribini yaşamış bir ülke olarak, günümüzde de ülkede kaçak et, at ve eşek etleri ile çok kısa sürede kesime hazır hale getirilen tavuk etlerinin piyasaya sürülmesi gibi vakaların yaşanması, tüketicilerin kırmızı et ve tavuk etine olan ilgisini giderek azalttığı düşünülmektedir. Ülkede hayvansal protein kaynaklarında gözlenen bu gibi sorunlar, özellikle alternatif protein kaynakları arasında yer alan ve uzmanlar tarafından tüketimi tavsiye edilen balık etine olan talebi artıracağı düşünülmektedir. Konunun da bu açıdan önemli olduğu düşünülmektedir.

$\mathrm{Bu}$ çalışmayla; araştırma alanında tüketicilerin balık eti tüketim tercihlerini, tüketim şekillerini ve tüketici kararlarını etkileyen faktörlerin belirlenmesi amaçlanmıştır. $\mathrm{Bu}$ amaçla, satın alma öncesi davranışların neler olduğu, tüketimin ne şekilde gerçekleştiği ve tüketim sonrası tutumların neler olduğu tespit edilmeye çalışılmış ve bu tespitlerden yola çıkarak mevcut durumu ortaya koymaya, tüketicilere ve sektöre yapıcı mesajlar verilmeye çalışılmıştır.

Araştırma sonuçlarının, özellikle su ürünleri sektörü için üretim-pazarlama-tüketim zincirinin geliştirilmesinde, firmaların pazarlama stratejilerini ve hedef kitlelerini yeniden revize etmelerinde katkılar sağlayacağı düşünülmektedir. Ayrıca et ve et ürünleri sektöründe karar vericilerin oluşturacağ uygulayacağı strateji ve politikaların amacına ulaşabilmesi için çalışma bulgularından yararlanılmasının oldukça faydalı olacağı düşünülmektedir.

\section{MATERYAL ve METOT}

Çalışmanın ana materyalini, 2014 Eylül ve Ekim aylarında Kahramanmaraş kent merkezinde ikamet eden tüketiciler ile yüz yüze görüşme şeklinde yapılan anketlerden elde edilen veriler oluşturmaktadır. Anket formunun oluşturulmasında konu ile ilgili literatürde yer alan yerli ve yabancı çalışmalar incelenmiş ve arzu edilen bilgileri en iyi şekilde ifade eden sorular hazırlanmıştır. Anket uygulanmadan önce pilot anket çalışması yapılmış, gerekli düzeltmeler yapılarak anket formu yeniden şekillendirildikten sonra tüketiciye yöneltilmiştir.

Öncelikle Kahramanmaraş kent merkezi sosyal ve ekonomik düzey bakımından düşük, orta ve yüksek olmak üzere üç bölgeye ayrılmıştır. Her bölgede yaşayan nüfus sayısı tespit edilmiş, bölgelerde katılımcılar tesadüfi olarak seçilerek toplam örnek sayısı bölgelere eşit olarak dağıtılmıştır. Böylece araştırma kapsamına alınan tüketicilerin ana kütleyi en iyi şekilde temsil eden örneklerden oluşmasına özen gösterilmiştir.

Örnek hacminin belirlenmesinde aşağıdaki oransal örnek hacmi formülü kullanılmıştır (Miran, 2013). 
Formülde;

$$
n=\frac{\mathbf{N p}(\mathbf{1}-\mathbf{p})}{(\mathbf{N}-\mathbf{1}) \boldsymbol{\sigma}^{2}{ }_{\widehat{\mathbf{p}}_{\mathbf{x}}}+\mathbf{p}(\mathbf{1}-\mathbf{p})}
$$

$$
\begin{aligned}
& \boldsymbol{\sigma}^{2} \hat{\boldsymbol{p}}_{\boldsymbol{x}}=\text { Oranın Varyansı } \\
& \boldsymbol{n}=\text { Örnek Hacmi } \\
& \boldsymbol{N}=\text { Ana Kitlenin Birey Sayısı } \\
& \boldsymbol{p}=\text { Oran (p: } 0.5 \text { alınmıştır. }) \\
& \\
& \mathrm{Z}_{\mathrm{a}} / 2\left(\mathrm{Q}_{\mathrm{p}}\right)=\mathrm{r} \quad 1.96\left(\mathrm{Q}_{\mathrm{p}}\right) \\
& \quad=0.05 \quad \mathrm{Q}_{\mathrm{p}}=0.02551
\end{aligned}
$$

$\mathrm{Bu}$ kriterlere göre $\% 95$ güven aralığı ve 0,05 hata payı ile örnek hacmi 384 olarak bulunmuştur.

Çalışmada elde edilen veriler tanımlayıcı istatistikler, Ki-kare bağımsızlık testi, Çoklu Doğrusal ve Lojistik Regresyon modelleri kullanılarak analiz edilmiştir.

Birden fazla bağımsız değişken kullanılarak yapılan çoklu regresyon analizi, aralarında sebep-sonuç bağlantısı bulunan bağımlı ve bağımsız değişkenler arasındaki ilişkinin modelini saptamakta ve bu model kullanılarak gelecekle ilgili tahminler yapılmasına imkan tanımaktadır. $\mathrm{Bu}$ yöntem ile balık eti tüketenlerin, tüketim miktarlarına etki eden faktörleri ve bu faktörlerin balık eti tüketim miktarını ne derecede etkiledikleri tahmin edilmeye çalışılmıştır (Takma ve ark., 2012).

Bağımlı değişkenin ikili $(0,1)$ olduğu durumlarda kullanılabilecek analiz yöntemlerinden biri Lojistik regresyon modelidir. Lojistik regresyon; cevap değişkeninin kategorik ve ikili, üçlü ve çoklu kategorilerde gözlendiği durumlarda açıklayıcı değişkenlerle neden sonuç ilişkisini belirlemede yararlanılan bir yöntemdir. Açıklayıcı değişkenlere göre cevap değişkeninin beklenen değerlerinin olasıllk olarak elde edildiği bir regresyon yöntemidir (Özdamar, 1997). Çalışmada, balık eti tüketip tüketmemede etkili olan faktörleri ve bu faktörlerin tüketimi ne derece etkilediğini belirlemek üzere Lojistik regresyon kullanılmıştır.

\section{BULGULAR VE TARTIŞMA}

\section{Tüketicilerin Demografik Özellikleri}

Çalışmada ankete katılan tüketicilerin \%54,7'sinin erkek, \%45,3'ünün kadın ve katılımcıların \%75,3'ünün ise evli olduğu tespit edilmiştir. Tüketicilerin $\% 51,3$ 'ü $\geqq 13$ yıl ve üstünde öğrenim görmüşlerdir. Tüketicilerin \%38,3'ü 31-45 yaş grubu aralığında ve ortalama yaş
38.44 olarak tespit edilmiştir. Anket yapılan tüketicilerin \%28,4'ü memurdur. Tüketicilerin $\% 58,9$ 'unun ailelerinin $\leqq 3$ kişiden oluştuğu ve ortalama hane halk1 büyüklüğünün 3,20 kişi olduğu tespit edilmiştir (Çizelge 1).

Tüketicilerin \%46,9'unun orta gelir grubunda olduğu ve ortalama gelirin $2.436,41 \mathrm{TL}$ olduğu tespit edilen diğer bir bulgudur. Kahramanmaraş'ta yapılan bazı çalışmalarda ailelerin aylık ortalama gelirleri şu şekilde tespit edilmiştir. Çukadar (2015) 2.145,32 TL, Beyazbayrak (2014) 2.118,03 TL ve Meral ve Şahin (2013) ise 1.960,17 TL dir.

Araştırmada ailelerin \%49,7'sinin aylık gıda harcamasının 500 TL'nin altında olduğu, ortalama gıda harcamasının ise 567,76 TL olduğu tespit edilmiştir. Hanehalkı geliri içinde toplam gıda harcamalarının oranı ise \%29 olarak hesaplanmıştır. Ailedeki çalışan sayısı incelendiğinde katılımcıların \%46,9'u ailesinde 2 kişinin çalıştığını beyan ederken, ortalama çalışan sayısı 1.60 kişi olarak tespit edilmiştir (Çizelge 1).

Çalışmada anket yapılan tüketiciler vücut kitle endekslerine göre risk gruplarına ayrılmıştır. Buna göre ankete katılanların \%5,7'sinin düşük kilolu (zayıf), $\% 43,2$ 'sinin normal kilolu, \%38' inin fazla kilolu, \%13 'ünün ise obez olduğu ve genel ortalamanın $(2,61)$ fazla kilolu (sağlıksız) olduğu tespit edilmiştir (Çizelge 1). TÜIKK verilerine göre ülke geneli bireylerin vücut kitle endeksleri incelendiğinde; 15 yaş ve üstü bireylerin \%4,2'sinin düşük kilolu, \%42,2'sinin normal kilolu, $\% 33,7$ 'sinin fazla kilolu ve \%19,9'unun ise obez olduğu ve genel ortalaması ise $(2,68)$ fazla kilolu olduğu tespit edilmiştir (Anonim, 2014b). Çalışma sonuçları ile TÜİK verileri benzerlik göstermiştir.

\section{Balık Eti Tüketim Yapısı}

Çalışmada ankete katılan tüketicilere balık eti ile ilgili satın alma ve tüketim şekilleri hakkında çeşitli sorular yöneltilmiştir. Çizelge 2'de cinsiyet, eğitim ve gelir gruplarına ilişkin oransal bilgiler verilmiştir. Ayrıca değişkenler arasında ki-kare bağımsızlık testi uygulanmış ve bunlara ait istatistiksel anlamlılık değerleri tespit edilmiştir.

Araştırmada balık eti tüketenlerin oranı \%84,6 olarak tespit edilmiş olup, kişi başı ortalama balık eti tüketim ve harcama miktarları sirasiyla $0,344 \mathrm{~kg} / \mathrm{ay}$ ve 8,45 TL/ay olarak tespit edilmiştir. 
Çizelge 1. Tüketicilerin Demografik Özellikleri

\begin{tabular}{|c|c|c|c|c|c|c|}
\hline $\begin{array}{l}\text { Demografik } \\
\text { Özellikler }\end{array}$ & $\begin{array}{c}\text { Kişi } \\
\text { Sayısı }\end{array}$ & $\begin{array}{c}\text { Oran } \\
(\%)\end{array}$ & \multirow{2}{*}{$\begin{array}{l}\text { Demografik } \\
\text { Özellikler } \\
\end{array}$} & \multicolumn{2}{|c|}{$\begin{array}{c}\text { Kişi } \\
\text { Sayısı }\end{array}$} & $\begin{array}{c}\text { Oran } \\
(\%)\end{array}$ \\
\hline Cinsiyet & & & & & & \\
\hline Erkek & 210 & 54,7 & Evli & & & 75,3 \\
\hline Kadın & 174 & 45,3 & Bekar & & & 24,7 \\
\hline Gelir Grupları & & & Yaş Grupları & & & \\
\hline Alt Gelir Grb. $(\leq 1500 \mathrm{TL})$ & 95 & 24,7 & $\leq 30$ & & & 33,6 \\
\hline Orta Gelir Grb.(1501-2999 TL) & 180 & 46,9 & $31-45$ & & & 38,3 \\
\hline Yüksek Gelir Grb. (>2999 TL) & 109 & 28,4 & $\geq 46$ & & & 28,1 \\
\hline $\begin{array}{l}\text { Eğitim } \\
\text { Seviyesi }\end{array}$ & Erkek / Kadın & $\begin{array}{l}\text { Oran } \\
(\%)\end{array}$ & $\begin{array}{l}\text { Meslek } \\
\text { Grupları }\end{array}$ & & & \\
\hline Yükseköğretim $(\geq 13)$ & $0,56 \quad 0,44$ & 51,3 & Esnaf & & & 11,5 \\
\hline Ortaöğretim (9-12) & $0,65 \quad 0,35$ & 28,6 & Memur & & & 28,4 \\
\hline İlköğretim $(\leq 8)$ & $0,36 \quad 0,64$ & 20,1 & İşçi & & & 11,5 \\
\hline Hane Halkı Sayısı & & & Emekli & & & 5,5 \\
\hline$\leq 3$ & 226 & 58,9 & Öğretmen & & & 3,4 \\
\hline $4-5$ & 140 & 36,5 & Ev Hanımı & & & 14,3 \\
\hline$\geq 6$ & 18 & 4,6 & Serbest Meslek & & & 10,9 \\
\hline Ailedeki Çalışan Sayısı & & & Öğrenci & & & 3,1 \\
\hline$\leq 1$ & 179 & 46,6 & Diğer (Dr., Müh., Mimar) & & & 11,4 \\
\hline 2 & 180 & 46,9 & $\begin{array}{l}\text { Vücut Kitle Endeksi } \\
\text { Risk Grupları }\end{array}$ & Erkek & Kadın & $\begin{array}{l}\text { Oran } \\
(\%)\end{array}$ \\
\hline$\geq 3$ & 25 & 6,5 & 1>Zayıf (Sağlıksı) & 0,8 & 4,9 & 5,7 \\
\hline Aylık Gıda Harcama Miktarı & & & $\begin{array}{l}\text { 2>Normal Kilolu } \\
\text { (Sağlıklı) }\end{array}$ & 21,9 & 21,4 & 43,3 \\
\hline$\leq 500 \mathrm{TL}$ & 191 & 49,7 & 3>Fazla Kilolu (Sağlıksız) & 26,0 & 12,0 & 38,0 \\
\hline $501-800 \mathrm{TL}$ & 168 & 43,8 & 4>Obez-Şişman (I. Der.) & 4,4 & 6,3 & 10,7 \\
\hline$>800 \mathrm{TL}$ & 25 & 6,5 & 5>Aşır1-Obez (II. Der.) & 1,5 & 0,8 & 2,3 \\
\hline
\end{tabular}

Çizelge 2. Önceki Çalışmalarda Tespit Edilen Tüketim Miktarları

\begin{tabular}{|c|c|c|c|}
\hline \multirow{2}{*}{ Yazar } & \multirow{2}{*}{ Yil } & \multirow{2}{*}{$\begin{array}{c}\text { Araştırma } \\
\text { Bölgesi }\end{array}$} & \multirow{2}{*}{$\begin{array}{c}\text { Aylık Tüketim Miktarı (kg) } \\
\text { Balık } \\
\end{array}$} \\
\hline & & & \\
\hline Beyazbayrak & 2014 & Kahramanmaraş & 0,500 \\
\hline Temel & 2014 & Rize & 1,673 \\
\hline Olgunoğlu ve ark. & 2014 & Adiyaman & 0,251 \\
\hline Nalinci & 2013 & Amasya & 0,422 \\
\hline Çiçek ve ark. & 2013 & Elazı $\breve{g}$ & 0,275 \\
\hline Yüksel ve ark. & 2011 & Tunceli & 0,342 \\
\hline Al-Shuaibi & 2011 & Suudi Arabistan & 1,119 \\
\hline FAO & 2011 & $\mathrm{ABD}$ & 1,000 \\
\hline FAO & 2011 & Almanya & 1,015 \\
\hline FAO & 2011 & Fransa & 1,877 \\
\hline FAO & 2011 & İsrail & 1,626 \\
\hline FAO & 2011 & İran & 0,667 \\
\hline FAO & 2011 & Yunanistan & 1,159 \\
\hline FAO & 2011 & Türkiye & 0,564 \\
\hline FAO & 2011 & Dünya & 1,185 \\
\hline Karakaş & 2010 & Tokat & 1,118 \\
\hline Adıgüzel ve ark. & 2009 & Tokat & 1,226 \\
\hline Akbay ve ark. & 2008 & Türkiye & 0,249 \\
\hline Hatırlı ve ark. & 2007 & Isparta & 1,030 \\
\hline Maltacık & 2006 & Elazı $\breve{g}$ & 0,837 \\
\hline Paksoy & 1998 & Kahramanmaraş & 0,261 \\
\hline
\end{tabular}


Çalışmada ankete katılanların \%45'i aylık 0,250 kg'dan daha az tüketim yapmışlardır. Gruplar arası en yüksek balık tüketim üniversite mezunları $(p<0.1)$ ve orta gelir grubu $(\mathrm{p}<0.05)$ olarak tespit edilmiştir. Çalışmada balık etini erkekler (\%60) kadınlardan (\%40) daha fazla tercih etmiş ve balık eti tüketimi ile cinsiyet arasında istatistiki olarak anlamlı bir ilişki tespit edilmiştir $(\mathrm{p}<0.01)$ (Çizelge3).

Beyazbayrak (2014) Kahramanmaraş’ta y1llık kişi başı balık tüketiminin yaklaşık $6 \mathrm{~kg}$ olduğunu tespit etmiştir. Aynı çalışmada cinsiyetler ile balık tüketimi arasında istatistiksel açıdan anlamlı bir fark $(0,05>0,000)$ olduğu da tespit edilmiştir. Temel (2014) Rize ilinde kişi başına balık tüketimini 20,07 kg/yıl olarak hesaplamış ve bunun Türkiye ortalamasının yaklaşık üç katı olduğunu belirtmiştir. Çalışmalarda tespit edilen tüketim miktarlarına bakıldığı zaman özellikle Karadeniz illeri ve denize kıyısı olan diğer illerde balık tüketim miktarlarının yüksek olduğu görülmektedir. Bu duruma neden olarak bu illerde balık arzının fazla olmasına bağlı olarak fiyatların daha ucuz olması ve bu illerde balık tüketiminin bir kültür haline dönüşmüş olması gösterilebilir. Kahramanmaraş ilinin deniz kenarında bulunmaması ve tüketicilerin deniz balıklarından çok hoşlanmamaları sebebiyle bu durum normal olarak görülebilir.

Balık eti tüketim miktarı ile cinsiyet $(\mathrm{p}<0.01)$, eğitim $(p<0.05)$ ve gelir $(p<0.05)$ arasında anlamlı bir ilişki tespit edilmiştir. Eğitim seviyesi yükseldikçe balık eti tüketim miktarının da arttığı gözlenmiştir (Çizelge 4). Yüksek ve orta gelir guruplarında alt gelir gurubuna göre daha fazla balık eti tüketimi söz konusu olmuştur (Çizelge 4). Beyazbayrak (2014) çalışmasında, balık tüketimi ile eğitim durumu arasında istatistiksel açıdan anlamlı bir fark $(0,05<0,123)$ olmadığını, gelir ile balık tüketip tüketmeme arasında ise istatistiksel açıdan anlamlı bir fark $(0,05>0,004)$ olduğu tespit etmiştir.

Çalışmada balık eti fiyatı (4,09 likert ortalama) ankete katılanlarca kesinlikle pahalı bulunmuştur. Balık eti tüketiciler tarafından $\% 80$ oranla balık halinden alınırken, \%78 oranla açık alım (ambalajsız) tercih edilmiştir. Balık etini satın alma yeri ve satın alma şekli ile cinsiyet $(p<0.01)$ ve gelir $(p<0.05)$ arasında anlaml bir ilişki tespit edilmiştir (Çizelge 3 ve 5 ).

Balık eti, tüketiciler tarafindan $\% 45$ oranla sağlıklı olduğu düşünüldüğü için tercih edilmiştir. Balık etini tercih etme nedeni ile cinsiyet $(\mathrm{p}<0.01)$ arasında anlaml bir ilişki tespit edilmiştir. Balık eti tüketiminde ayda birkaç kez tüketim \%54 oranla ilk sırada yer almıştır. Balık eti tüketim sıklığı ile cinsiyet $(\mathrm{p}<0.01)$ ve eğitim $(\mathrm{p}<0.01)$ arasında istatistiki olarak anlamlı bir ilişki tespit edilmiştir (Çizelge 3 ve 4). Beyazbayrak (2014) çalışmasında, tüketiciler tarafından balık $(\% 66,0)$ en çok faydalı olduğu düşünüldüğü için tercih edildiğini belirlemiştir.

Çalışmada, balık etini yeterli miktarda tükettiklerini düşünenlerin oranı \%47 olarak tespit edilmiştir. Balık etini yeteri kadar tüketme durumu ile cinsiyet $(\mathrm{p}<0.01)$ ve gelir $(\mathrm{p}<0.01)$ arasında istatistiksel olarak anlamlı bir ilişki tespit edilmiştir (Çizelge 3 ve 5). Tüketiciler (\%89) bir önceki yıla oranla balık eti tüketim miktarlarında herhangi bir değişimin olmadığını beyan etmişlerdir. Bir önceki yıla oranla balık eti tüketim miktarındaki değişme ile eğitim $(\mathrm{p}<0.05)$ arasında anlamlı bir ilişki tespit edilmiştir (Çizelge 4). Tüketiciler, balık fiyatlarındaki belirgin artışlara ve enflasyona bağlı olarak alım güçlerinin her geçen yıl düştüğünü bilmelerine rağmen, balık eti tüketme arzusu ile hareket ettiklerini beyan etmişlerdir. Bu yüzden balık tüketim miktarlarında negatif bir değişim olmamıştır.

Tüketiciler balık etini (\%37) en çok firında pişirerek tüketmeyi tercih etmişlerdir. Balık etini tüketim şekli ile cinsiyet $(p<0.01)$, eğitim $(p<0.1)$ ve gelir $(p<0.05)$ arasında istatistiki olarak anlamlı bir ilişki tespit edilmiştir (Çizelge 3, 4 ve 5). Beyazbayrak (2014) çalışmasında, tüketicilerin balığı en çok $(\% 35,3)$ firında pişirerek tükettiklerini tespit etmiştir. Çalışmada tüketicilere balık ile birlikte ne yer ve ne içersiniz sorusu sorulmuştur. Bunun üzerine tüketiciler (\%83) en fazla salata/yeşillik cevabını verirken; içecek olarak da en fazla gazlı içecek $(\% 43)$ daha sonra su (\%31) tercih edilmiştir. Balık ile birlikte yenen ve içilen ile cinsiyet $(p<0.01)$ ve gelir $(p<0.1)$ arasında anlamlı bir ilişki tespit edilmiştir (Çizelge 3 ve 5).

Araştırmada, ev dışında balık eti tüketirim diyenlerin oranı \%36 olarak gerçekleşirken, bu tüketimin büyük kısmı piknikte (\%21) yapılmıştır. Balık etinin ev dışı tüketimi ile cinsiyet $(\mathrm{p}<0.05)$, eğitim $(\mathrm{p}<0.01)$ ve gelir $(\mathrm{p}<0.1)$ arasında anlamlı bir ilişki tespit edilmiştir (Çizelge 3, 4 ve 5). İlde yayla ve mesire alanlarının çok olması piknik kültürünü geliştirmiştir. Piknikte daha çok kırmızı et tüketimi tercih edilmiş ancak balık tüketiminin de kısmen arttığı görülmektedir. Beyazbayrak (2014) çalışmasında, tüketicilerin balığı en çok $(\% 49,5)$ evde, daha sonra piknikte veya açık havada $(\% 35,8)$ yemeyi tercih ettiklerini tespit etmiştir.

Katılımcılar çalışmada balık etin sağlıklı ve dengeli beslenmede kesinlikle önemli (4,28 likert ortalama) olduğunu vurgulamışlardır. Cinsiyet ile balık etinin sağlıklı ve dengeli beslenmedeki önemi $(p<0.05)$ arasında istatistiksel olarak anlamlı bir ilişki tespit edilmiştir. Eğitim düzeyi yükseldikçe balık eti tüketiminin sağlık açısından önemli olduğunu düşünenlerin oranı artmıştır. Yani eğitim ile insanların bilinçlenmeye başladığı bunun da sağlıklı yaşamaya olan ilgiyi arttığı görülmektedir. (Çizelge 4). Beyazbayrak (2014) çalışmasında, katılımcılar (\%90) balığın sağlık açısından faydalarını bildiklerini belirtmiştir.

Tüketicilerin balık satış noktalarına olan güven düzeylerinin likert ortalaması $(2,97)$ orta düzeyde gerçekleşmiştir. Ayrıca yetkili kurumlarca balık satışının kontrolünün az yapıldı̆̆ düşünülmektedir. Balık satış noktalarına olan güven 
düzeyi ile eğitim $(\mathrm{p}<0.05)$ ve gelir $(\mathrm{p}<0.01)$ arasında; yetkili kurumlarca balık satışının kontrolünün yapılıp yapılmama durumu ile de cinsiyet $(\mathrm{p}<0.1)$, eğitim $(p<0.05)$ ve gelir $(p<0.01)$ arasında istatistiki olarak anlamlı bir ilişski tespit edilmiştir (Çizelge 3, 4 ve 5).

Çalışmada balık tüketimi en fazla kış aylarında $(\% 49,5)$ daha sonra sonbaharda $(\% 33,5)$ gerçekleşirken, tüketiciler tarafindan en çok hamsi (\%26) ve alabalık (\%26) tercih edilmiştir. Tercih edilen balık türü ile cinsiyet $(p<0.01)$ ve gelir $(p<0.1)$ arasında istatistiki olarak anlamlı bir iliş̧i tespit edilmiştir (Çizelge 3 ve 5). Beyazbayrak (2014) çalışmasında, katılımcılar tarafindan en çok tüketilen balık türünün (\%40) alabalık ve hamsi $(\% 19,5)$ olduğunu belirtmiştir. Temel (2014) çalı̧̧masında, hanelerin sonbahar ve kışın en çok barbunu, sonrasinda hamsiyi; ilkbahar ve yazın ise büyük çoğunlukla alabalık ve istavriti tercih ettiklerini tespit etmiştir. Olgunoğlu ve ark. (2014) çalışmalarında, balık eti tüketenlerin öncelikli tercihlerinin (\%70) tatlı su türlerinden yana olduğunu, bu türler içerisinde en fazla sazanın (\%36) daha sonra alabalı̆̆ın (\%22) tercih edildiğini belirlemişlerdir. Deniz balıkları içerisinde ise \%19 ile hamsinin ilk sırada yer aldığ tespit edilmiş̧tir. Yüksel ve ark. (2011) çalışmalarında, il genelinde en beğenilen türün doğal alabalık, en fazla tüketilen türün ise hamsi olduğu tespit etmişlerdir.

Çizelge 3. Cinsiyet Gruplarının Oransal Verileri ve Anlamlılık Düzeyleri

\begin{tabular}{|c|c|c|c|c|c|}
\hline \multirow{2}{*}{ Sorular } & \multirow{2}{*}{ Seçenekler } & \multicolumn{3}{|c|}{ Cinsiyet } & \multirow{2}{*}{$\begin{array}{l}\text { Örneklem } \\
\text { Oranı }\end{array}$} \\
\hline & & Erkek & Kadın & $\mathrm{P}$ & \\
\hline \multirow{2}{*}{ Balık Eti Tüketiyor musunuz? } & Evet & 0,60 & 0,40 & 0,000 & 0,85 \\
\hline & Hayır & 0,25 & 0,75 & $*$ & 0,15 \\
\hline \multirow{3}{*}{ Balık Eti Tüketim Miktarınız Nedir? } & 1. grup $(<0,25 \mathrm{~kg})$ & 0,41 & 0,59 & \multirow{3}{*}{$\begin{array}{c}0,000 \\
*\end{array}$} & 0,45 \\
\hline & 2. grup $(0,25-0,50 \mathrm{~kg})$ & 0,65 & 0,35 & & 0,32 \\
\hline & 3. grup $(>0,50 \mathrm{~kg})$ & 0,67 & 0,33 & & 0,23 \\
\hline \multirow{5}{*}{ Balık Eti Fiyatını Nasıl Değerlendiriyorsunuz? } & Kesinlikle Ucuz & 1,00 & 0,00 & \multirow{5}{*}{0,648} & 0,01 \\
\hline & Ucuz & 0,75 & 0,25 & & 0,02 \\
\hline & Orta & 0,53 & 0,47 & & 0,24 \\
\hline & Pahalı & 0,56 & 0,44 & & 0,35 \\
\hline & Kesinlikle pahalı & 0,53 & 0,47 & & 0,38 \\
\hline \multirow{4}{*}{ Balık Etini Tercih Etme Nedeniniz Nedir? } & Lezzetli olması & 0,57 & 0,43 & \multirow{4}{*}{$\begin{array}{c}0,000 \\
*\end{array}$} & 0,15 \\
\hline & Sağlıklı olması & 0,57 & 0,43 & & 0,45 \\
\hline & Besleyici olması & 0,67 & 0,33 & & 0,25 \\
\hline & Tüketmem & 0,25 & 0,75 & & 0,15 \\
\hline \multirow{4}{*}{ Balık Etini Nereden Satın Alırsınız? } & Kasap / Et tanzim & 0,33 & 0,67 & \multirow{4}{*}{$\begin{array}{l}0,000 \\
*\end{array}$} & 0,02 \\
\hline & Süpermarket / Market & 0,56 & 0,44 & & 0,03 \\
\hline & Balık halinden & 0,61 & 0,39 & & 0,80 \\
\hline & Tüketmem & 0,25 & 0,75 & & 0,15 \\
\hline \multirow{4}{*}{ Balık Eti Tüketim Sıklığınız Nedir? } & Haftada birkaç kere & 0,62 & 0,38 & \multirow{4}{*}{$\begin{array}{c}0,000 \\
*\end{array}$} & 0,19 \\
\hline & Ayda birkaç kere & 0,62 & 0,38 & & 0,55 \\
\hline & Yilda birkaç kere & 0,48 & 0,52 & & 0,11 \\
\hline & Tüketmem & 0,25 & 0,75 & & 0,15 \\
\hline \multirow{3}{*}{$\begin{array}{l}\text { Bir Önceki Yıla Göre Balık Eti Tüketim Miktarınız } \\
\text { Değişti mi? }\end{array}$} & Azaldı & 0,40 & 0,60 & \multirow{3}{*}{0,309} & 0,05 \\
\hline & Değişmedi & 0,55 & 0,45 & & 0,89 \\
\hline & Artt1 & 0,63 & 0,37 & & 0,06 \\
\hline \multirow{4}{*}{ Balık Etini Nasıl Satın Alırsınız? } & Ambalajlı & 0,60 & 0,40 & \multirow{4}{*}{$\begin{array}{l}0,000 \\
*\end{array}$} & 0,04 \\
\hline & Açık & 0,61 & 0,39 & & 0,79 \\
\hline & Dondurulmuş & 0,22 & 0,78 & & 0,02 \\
\hline & Tüketmem & 0,25 & 0,75 & & 0,15 \\
\hline \multirow{5}{*}{ Balık Etini Nasıl Tüketirsiniz? } & Firında & 0,61 & 0,39 & \multirow{5}{*}{$\begin{array}{c}0,000 \\
*\end{array}$} & 0,38 \\
\hline & Izgara / Mangal & 0,58 & 0,42 & & 0,19 \\
\hline & Yağda kızartma & 0,56 & 0,44 & & 0,24 \\
\hline & Buğulama & 0,81 & 0,19 & & 0,04 \\
\hline & Tüketmem & 0,25 & 0,75 & & 0,15 \\
\hline \multirow{4}{*}{ Balık Etini Ev dışında Tüketir misiniz? } & Lokanta & 0,66 & 0,34 & \multirow{4}{*}{$\begin{array}{l}0,037 \\
* *\end{array}$} & 0,12 \\
\hline & Yemekhane & 0,69 & 0,31 & & 0,03 \\
\hline & Piknik & 0,63 & 0,37 & & 0,21 \\
\hline & Ev diş1 tüketmem & 0,49 & 0,51 & & 0,64 \\
\hline
\end{tabular}


Çizelge 3. (devam) Cinsiyet Gruplarının Oransal Verileri ve Anlamlılık Düzeyleri

\begin{tabular}{|c|c|c|c|c|c|}
\hline \multirow{2}{*}{ Sorular } & \multirow{2}{*}{ Seçenekler } & \multicolumn{3}{|c|}{ Cinsiyet } & \multirow{2}{*}{$\begin{array}{c}\text { Örneklem } \\
\text { Oranı }\end{array}$} \\
\hline & & Erkek & Kadın & $\mathrm{p}$ & \\
\hline \multirow{5}{*}{$\begin{array}{l}\text { Balık Etinin Sağlıklı ve Dengeli Beslenmedeki Önem } \\
\text { Düzeyi Nedir? }\end{array}$} & Kesinlikle etkisiz & 0,41 & 0,59 & \multirow{5}{*}{$\begin{array}{c}0,014 \\
* *\end{array}$} & 0,06 \\
\hline & Az etkili & 1,00 & 0,00 & & 0,01 \\
\hline & Orta & 0,76 & 0,24 & & 0,04 \\
\hline & Etkili & 0,60 & 0,40 & & 0,38 \\
\hline & Kesinlikle etkili & 0,49 & 0,51 & & 0,51 \\
\hline \multirow{2}{*}{$\begin{array}{l}\text { Balık Etini Yeterli Miktarda Tükettiğinizi Düşünüyor } \\
\text { musunuz? }\end{array}$} & Evet & 0,64 & 0,36 & \multirow{2}{*}{$\begin{array}{c}0,001 \\
*\end{array}$} & 0,47 \\
\hline & Hayır & 0,47 & 0,53 & & 0,53 \\
\hline \multirow{4}{*}{$\begin{array}{l}\text { Balık Etini Satın Alma Yerinizi Belirleyen Faktör } \\
\text { Nedir? }\end{array}$} & Eve yakın olması & 0,75 & 0,25 & \multirow{4}{*}{$\begin{array}{c}0,000 \\
*\end{array}$} & 0,02 \\
\hline & $\begin{array}{l}\text { Arkadaş / Dost } \\
\text { tavsiyesi }\end{array}$ & 0,72 & 0,28 & & 0,22 \\
\hline & $\begin{array}{l}\text { Alışkanlık / Sürekli } \\
\text { alım yeri }\end{array}$ & 0,55 & 0,45 & & 0,61 \\
\hline & Tüketmem & 0,25 & 0,75 & & 0,15 \\
\hline \multirow{5}{*}{ Et Satış Noktalarına Güven Düzeyiniz Nedir? } & $\begin{array}{l}\text { Kesinlikle } \\
\text { güvenmiyorum }\end{array}$ & 0,73 & 0,27 & \multirow{5}{*}{0,166} & 0,10 \\
\hline & Güvenim az & 0,49 & 0,51 & & 0,24 \\
\hline & Orta & 0,54 & 0,46 & & 0,28 \\
\hline & Güveniyorum & 0,53 & 0,47 & & 0,34 \\
\hline & Kesinlikle güveniyorum & 0,60 & 0,40 & & 0,04 \\
\hline \multirow{5}{*}{ Balık Etinin Satış Kontrolü Sizce Yapılıyor mu? } & Kesinlikle yapılmıyor & 0,68 & 0,32 & \multirow{5}{*}{$\begin{array}{c}0,069 \\
* * *\end{array}$} & 0,20 \\
\hline & Az yapiliyor & 0,54 & 0,46 & & 0,27 \\
\hline & Orta & 0,49 & 0,51 & & 0,27 \\
\hline & Yapıliyor & 0,49 & 0,51 & & 0,23 \\
\hline & Kesinlikle yapılıyor & 0,64 & 0,36 & & 0,03 \\
\hline \multirow{2}{*}{ Et Tüketmenize Engel Olan Bir Hastalığınız Var mı? } & Evet & 0,58 & 0,42 & \multirow{2}{*}{0,411} & 0,34 \\
\hline & Hayır & 0,53 & 0,47 & & 0,66 \\
\hline \multirow{4}{*}{ Balık Eti İle Birlikte Ne Yersiniz? } & Salata/Yeşillik & 0,61 & 0,39 & \multirow{4}{*}{$\begin{array}{l}0,000 \\
*\end{array}$} & 0,83 \\
\hline & Yoğurt/Cacık & 0,00 & 1,00 & & 0,01 \\
\hline & Sebze & 0,40 & 0,60 & & 0,01 \\
\hline & Tüketmem & 0,25 & 0,75 & & 0,15 \\
\hline \multirow{6}{*}{ Balık Eti İle Birlikte Ne İçersiniz? } & Alkollü içecek & 0,64 & 0,36 & \multirow{6}{*}{$\begin{array}{l}0,000 \\
*\end{array}$} & 0,07 \\
\hline & Gazlı içecek & 0,57 & 0,43 & & 0,42 \\
\hline & Ayran & 0,64 & 0,36 & & 0,03 \\
\hline & $\mathrm{Su}$ & 0,63 & 0,37 & & 0,31 \\
\hline & Şalgam & 0,57 & 0,43 & & 0,02 \\
\hline & Tüketmem & 0,25 & 0,75 & & 0,15 \\
\hline \multirow{9}{*}{ Hangi Balık Türünü Tüketirsiniz? } & Hamsi & 0,58 & 0,42 & \multirow{9}{*}{$\begin{array}{l}0,000 \\
*\end{array}$} & 0,26 \\
\hline & Levrek & 0,58 & 0,42 & & 0,10 \\
\hline & Çipura & 0,79 & 0,21 & & 0,05 \\
\hline & Alabalık & 0,63 & 0,37 & & 0,26 \\
\hline & Palamut & 0,60 & 0,40 & & 0,10 \\
\hline & Somon & 0,43 & 0,57 & & 0,06 \\
\hline & İstavrit & 0,50 & 0,50 & & 0,01 \\
\hline & Sazan & 1,00 & 0,00 & & 0,01 \\
\hline & Tüketmem & 0,25 & 0,75 & & 0,15 \\
\hline
\end{tabular}


Çizelge 4. Eğitim Gruplarının Oransal Verileri ve Anlamlılık Düzeyleri

\begin{tabular}{|c|c|c|c|c|c|c|}
\hline \multirow[b]{2}{*}{ Sorular } & \multirow[b]{2}{*}{ Seçenekler } & \multicolumn{3}{|c|}{ Eğitim Grupları } & \multirow[b]{2}{*}{$\mathrm{p}$} & \multirow{2}{*}{$\begin{array}{c}\text { Örneklem } \\
\text { Oranı } \\
(\%)\end{array}$} \\
\hline & & $\begin{array}{c}\text { İköğretim } \\
(=<8)\end{array}$ & $\begin{array}{l}\text { Ortaöğretim } \\
(9-12)\end{array}$ & $\begin{array}{l}\text { Yükseköğretim } \\
(=>13)\end{array}$ & & \\
\hline \multirow{2}{*}{ Balık Eti Tüketiyor musunuz? } & Evet & 0,18 & 0,28 & 0,54 & \multirow{2}{*}{$\begin{array}{c}0,051 \\
* * *\end{array}$} & 0,85 \\
\hline & Hayır & 0,30 & 0,31 & 0,39 & & 0,15 \\
\hline \multirow{3}{*}{$\begin{array}{l}\text { Balık Eti Tüketim Miktarınız } \\
\text { Nedir? }\end{array}$} & 1. grup $(<0,25 \mathrm{~kg})$ & 0,28 & 0,27 & 0,45 & \multirow{3}{*}{$\begin{array}{l}0,018 \\
* *\end{array}$} & 0,45 \\
\hline & 2. grup $(0,25-0,50 \mathrm{~kg})$ & 0,13 & 0,31 & 0,56 & & 0,32 \\
\hline & 3. grup $(>0,50 \mathrm{~kg})$ & 0,15 & 0,29 & 0,56 & & 0,23 \\
\hline \multirow{5}{*}{$\begin{array}{l}\text { Balık Eti Fiyatını Nasıl } \\
\text { Değerlendiriyorsunuz? }\end{array}$} & Kesinlikle Ucuz & 0,00 & 1,00 & 0,00 & \multirow{5}{*}{$\begin{array}{l}0,073 \\
* * *\end{array}$} & 0,01 \\
\hline & Ucuz & 0,12 & 0,38 & 0,50 & & 0,02 \\
\hline & Orta & 0,15 & 0,29 & 0,56 & & 0,24 \\
\hline & Pahalı & 0,14 & 0,29 & 0,57 & & 0,35 \\
\hline & Kesinlikle pahalı & 0,29 & 0,27 & 0,44 & & 0,38 \\
\hline \multirow{4}{*}{$\begin{array}{l}\text { Balık Etini Tercih Etme Nedeniniz } \\
\text { Nedir? }\end{array}$} & Lezzetli olması & 0,12 & 0,31 & 0,57 & \multirow{4}{*}{0,242} & 0,15 \\
\hline & Sağlıklı olması & 0,20 & 0,29 & 0,51 & & 0,45 \\
\hline & Besleyici olması & 0,19 & 0,26 & 0,55 & & 0,25 \\
\hline & Tüketmem & 0,30 & 0,31 & 0,39 & & 0,15 \\
\hline \multirow{4}{*}{$\begin{array}{l}\text { Balık Etini Nereden Satın } \\
\text { Alırsınız? }\end{array}$} & Kasap / Et tanzim & 0,22 & 0,22 & 0,56 & \multirow{4}{*}{0,235} & 0,02 \\
\hline & Süpermarket / Market & 0,00 & 0,33 & 0,67 & & 0,03 \\
\hline & Balık halinden & 0,19 & 0,28 & 0,53 & & 0,80 \\
\hline & Tüketmem & 0,30 & 0,31 & 0,39 & & 0,15 \\
\hline \multirow{4}{*}{$\begin{array}{l}\text { Balık Eti Tüketim Sıklığınız } \\
\text { Nedir? }\end{array}$} & Haftada birkaç kere & 0,12 & 0,29 & 0,59 & \multirow{4}{*}{$\begin{array}{l}0,000 \\
*\end{array}$} & 0,19 \\
\hline & Ayda birkaç kere & 0,15 & 0,31 & 0,53 & & 0,55 \\
\hline & Y1lda birkaç kere & 0,41 & 0,14 & 0,45 & & 0,11 \\
\hline & Tüketmem & 0,31 & 0,31 & 0,39 & & 0,15 \\
\hline \multirow{3}{*}{$\begin{array}{l}\text { Bir Önceki Yıla Göre Balık Eti } \\
\text { Tüketim Miktarınız Değişti mi? }\end{array}$} & Azald 1 & 0,10 & 0,10 & 0,80 & \multirow{3}{*}{$\begin{array}{l}0,018 \\
* *\end{array}$} & 0,05 \\
\hline & Değişmedi & 0,21 & 0,30 & 0,49 & & 0,89 \\
\hline & Artt1 & 0,08 & 0,21 & 0,71 & & 0,06 \\
\hline \multirow{4}{*}{ Balık Etini Nasıl Satın Alırsınız? } & Ambalajlı & 0,07 & 0,47 & 0,48 & & 0,04 \\
\hline & Açık & 0,19 & 0,28 & 0,53 & & 0,79 \\
\hline & Dondurulmuş & 0,11 & 0,22 & 0,67 & 0,141 & 0,02 \\
\hline & Tüketmem & 0,30 & 0,31 & 0,39 & & 0,15 \\
\hline & Firında & 0,18 & 0,25 & 0,57 & & 0,38 \\
\hline & Izgara / Mangal & 0,11 & 0,28 & 0,61 & & 0,19 \\
\hline Balık Etini Nasıl Tüketirsiniz? & Yağda kızartma & 0,22 & 0,31 & 0,47 & $\begin{array}{l}0,005 \\
* * *\end{array}$ & 0,24 \\
\hline & Buğulama & 0,25 & 0,44 & 0,31 & & 0,04 \\
\hline & Tüketmem & 0,30 & 0,31 & 0,39 & & 0,15 \\
\hline & Lokanta & 0,08 & 0,32 & 0,60 & & 0,12 \\
\hline Balık Etini Ev dışında Tüketir & Yemekhane & 0,08 & 0,15 & 0,77 & 0,010 & 0,03 \\
\hline misiniz? & Piknik & 0,13 & 0,26 & 0,61 & $*$ & 0,21 \\
\hline & Ev dişı tüketmem & 0,25 & 0,30 & 0,45 & & 0,64 \\
\hline & Kesinlikle etkisiz & 0,14 & 0,32 & 0,55 & & 0,06 \\
\hline Balık Etinin Sağlıklı ve Dengeli & Az etkili & 0,00 & 0,50 & 0,50 & & 0,01 \\
\hline Beslenmedeki Önem Düzeyi & Orta & 0,12 & 0,41 & 0,47 & 0,199 & 0,04 \\
\hline Nedir? & Etkili & 0,15 & 0,33 & 0,51 & & 0,38 \\
\hline & Kesinlikle etkili & 0,25 & 0,23 & 0,52 & & 0,51 \\
\hline Balık Etini Yeterli Miktarda & Evet & 0,16 & 0,29 & 0,55 & & 0,47 \\
\hline Tükettiğinizi Düşünüyor musunuz? & Hayır & 0,23 & 0,29 & 0,48 & 0,149 & 0,53 \\
\hline & Eve yakın olması & 0,25 & 0,00 & 0,75 & & 0,02 \\
\hline Balık Etini Satın Alma Yerinizi & $\begin{array}{l}\text { Arkadaş / Dost } \\
\text { tavsiyesi }\end{array}$ & 0,19 & 0,28 & 0,53 & & 0,22 \\
\hline Belirleyen Faktör Nedir? & $\begin{array}{l}\text { Alışkanlık / Sürekli } \\
\text { alım yeri }\end{array}$ & 0,18 & 0,29 & 0,53 & 0,156 & 0,61 \\
\hline & Tüketmem & 0,30 & 0,31 & 0,39 & & 0,15 \\
\hline
\end{tabular}


Çizelge 4. (devam) Eğitim Gruplarının Oransal Verileri ve Anlamlılık Düzeyleri

\begin{tabular}{|c|c|c|c|c|c|c|}
\hline \multirow[b]{2}{*}{ Sorular } & \multirow[b]{2}{*}{ Seçenekler } & \multicolumn{3}{|c|}{ Eğitim Grupları } & \multirow[b]{2}{*}{$\mathrm{p}$} & \multirow{2}{*}{$\begin{array}{c}\text { Örneklem } \\
\text { Oranı } \\
(\%)\end{array}$} \\
\hline & & $\begin{array}{c}\text { İlköğretim } \\
(=<8)\end{array}$ & $\begin{array}{c}\text { Ortaöğretim } \\
(9-12)\end{array}$ & $\begin{array}{c}\text { Yükseköğretim } \\
(=>13)\end{array}$ & & \\
\hline \multirow{5}{*}{$\begin{array}{l}\text { Et Satış Noktalarına Güven } \\
\text { Düzeyiniz Nedir? }\end{array}$} & $\begin{array}{l}\text { Kesinlikle } \\
\text { güvenmiyorum }\end{array}$ & 0,12 & 0,48 & 0,40 & \multirow{5}{*}{$\begin{array}{c}0,026 \\
* *\end{array}$} & 0,10 \\
\hline & Güvenim az & 0,14 & 0,34 & 0,52 & & 0,24 \\
\hline & Orta & 0,19 & 0,28 & 0,53 & & 0,28 \\
\hline & Güveniyorum & 0,26 & 0,22 & 0,52 & & 0,34 \\
\hline & $\begin{array}{l}\text { Kesinlikle } \\
\text { güveniyorum }\end{array}$ & 0,27 & 0,07 & 0,66 & & 0,04 \\
\hline \multirow{5}{*}{$\begin{array}{l}\text { Balık Etinin Satış Kontrolü Sizce } \\
\text { Yapılıyor mu? }\end{array}$} & Kesinlikle yapilmiyor & 0,12 & 0,42 & 0,46 & \multirow{5}{*}{$\begin{array}{l}0,035 \\
* *\end{array}$} & 0,20 \\
\hline & Az yapıliyor & 0,18 & 0,27 & 0,55 & & 0,27 \\
\hline & Orta & 0,29 & 0,25 & 0,46 & & 0,27 \\
\hline & Yapılıyor & 0,20 & 0,25 & 0,55 & & 0,23 \\
\hline & Kesinlikle yapılıyor & 0,09 & 0,18 & 0,73 & & 0,03 \\
\hline \multirow{2}{*}{$\begin{array}{l}\text { Et Tüketmenize Engel Olan Bir } \\
\text { Hastalığınız Var mı? }\end{array}$} & Evet & 0,26 & 0,27 & 0,47 & \multirow{2}{*}{$\begin{array}{c}0,073 \\
* * *\end{array}$} & 0,34 \\
\hline & Hayır & 0,16 & 0,30 & 0,54 & & 0,66 \\
\hline \multirow{4}{*}{ Balık Eti İle Birlikte Ne Yersiniz? } & Salata/Yeşillik & 0,18 & 0,28 & 0,54 & \multirow{4}{*}{0,241} & 0,83 \\
\hline & Yoğurt/Cacık & 0,50 & 0,00 & 0,50 & & 0,01 \\
\hline & Sebze & 0,20 & 0,40 & 0,40 & & 0,01 \\
\hline & Tüketmem & 0,30 & 0,31 & 0,39 & & 0,15 \\
\hline \multirow{6}{*}{ Balık Eti İle Birlikte Ne İçersiniz? } & Alkollü içecek & 0,04 & 0,24 & 0,72 & \multirow{6}{*}{$\begin{array}{l}0,089 \\
* * *\end{array}$} & 0,07 \\
\hline & Gazlı içecek & 0,18 & 0,30 & 0,52 & & 0,42 \\
\hline & Ayran & 0,00 & 0,36 & 0,64 & & 0,03 \\
\hline & $\mathrm{Su}$ & 0,22 & 0,28 & 0,50 & & 0,31 \\
\hline & Şalgam & 0,43 & 0,14 & 0,43 & & 0,02 \\
\hline & Tüketmem & 0,30 & 0,31 & 0,39 & & 0,15 \\
\hline \multirow{9}{*}{ Hangi Balık Türünü Tüketirsiniz? } & Hamsi & 0,25 & 0,28 & 0,47 & \multirow{9}{*}{0,145} & 0,26 \\
\hline & Levrek & 0,13 & 0,37 & 0,50 & & 0,10 \\
\hline & Çipura & 0,00 & 0,21 & 0,79 & & 0,05 \\
\hline & Alabalık & 0,19 & 0,26 & 0,55 & & 0,26 \\
\hline & Palamut & 0,12 & 0,33 & 0,55 & & 0,10 \\
\hline & Somon & 0,22 & 0,26 & 0,52 & & 0,06 \\
\hline & İstavrit & 0,00 & 0,00 & 1,00 & & 0,01 \\
\hline & Sazan & 0,00 & 0,50 & 0,50 & & 0,01 \\
\hline & Tüketmem & 0,30 & 0,31 & 0,39 & & 0,15 \\
\hline
\end{tabular}

$0,01 *, 0,05 * *, 0,10 * * *$ önem düzeylerine göre değerlendirilmiştir. 
Çizelge 5. Gelir Gruplarının Oransal Verileri ve Anlamlılık Düzeyleri

\begin{tabular}{|c|c|c|c|c|c|c|}
\hline \multirow[b]{2}{*}{ Sorular } & \multirow[b]{2}{*}{ Seçenekler } & \multicolumn{3}{|c|}{ Gelir Grupları } & \multirow[b]{2}{*}{$\mathrm{p}$} & \multirow{2}{*}{$\begin{array}{l}\text { Örneklem } \\
\text { Oranı }(\%)\end{array}$} \\
\hline & & $\begin{array}{l}\text { Alt Gelir } \\
\text { Grubu }\end{array}$ & $\begin{array}{c}\text { Ort.Gelir } \\
\text { Grubu }\end{array}$ & $\begin{array}{c}\text { Yüksek } \\
\text { Gelir Grubu }\end{array}$ & & \\
\hline \multirow{2}{*}{ Balık Eti Tüketiyor musunuz? } & Evet & 0,26 & 0,44 & 0,30 & \multirow{2}{*}{$\begin{array}{c}0,029 \\
* *\end{array}$} & 0,85 \\
\hline & Hayır & 0,18 & 0,63 & 0,19 & & 0,15 \\
\hline \multirow{3}{*}{ Balık Eti Tüketim Miktarınız Nedir? } & 1. grup $(<0,25 \mathrm{~kg})$ & 0,23 & 0,56 & 0,21 & \multirow{3}{*}{$\begin{array}{l}0,020 \\
* *\end{array}$} & 0,45 \\
\hline & 2. grup $(0,25-0,50 \mathrm{~kg})$ & 0,28 & 0,40 & 0,32 & & 0,32 \\
\hline & 3. grup $(>0,50 \mathrm{~kg})$ & 0,23 & 0,40 & 0,37 & & 0,23 \\
\hline \multirow{5}{*}{$\begin{array}{l}\text { Balık Eti Fiyatını Nasıl } \\
\text { Değerlendiriyorsunuz? }\end{array}$} & Kesinlikle Ucuz & 0,00 & 1,00 & 0,00 & \multirow{5}{*}{0,230} & 0,01 \\
\hline & Ucuz & 0,63 & 0,37 & 0,00 & & 0,02 \\
\hline & Orta & 0,24 & 0,48 & 0,28 & & 0,24 \\
\hline & Pahalı & 0,21 & 0,46 & 0,33 & & 0,35 \\
\hline & Kesinlikle pahalı & 0,27 & 0,47 & 0,26 & & 0,38 \\
\hline \multirow{4}{*}{ Balık Etini Tercih Etme Nedeniniz Nedir? } & Lezzetli olması & 0,29 & 0,47 & 0,24 & \multirow{4}{*}{0,202} & 0,15 \\
\hline & Sağlıklı olması & 0,24 & 0,44 & 0,32 & & 0,45 \\
\hline & Besleyici olması & 0,26 & 0,43 & 0,31 & & 0,25 \\
\hline & Tüketmem & 0,18 & 0,63 & 0,19 & & 0,15 \\
\hline \multirow{4}{*}{ Balık Etini Nereden Satın Alırsınız? } & Kasap / Et tanzim & 0,11 & 0,67 & 0,22 & \multirow{4}{*}{$\begin{array}{l}0,019 \\
* *\end{array}$} & 0,02 \\
\hline & Süpermarket / Market & 0,11 & 0,22 & 0,67 & & 0,03 \\
\hline & Balık halinden & 0,27 & 0,44 & 0,29 & & 0,80 \\
\hline & Tüketmem & 0,18 & 0,63 & 0,19 & & 0,15 \\
\hline \multirow{4}{*}{ Balık Eti Tüketim Sıklığınız Nedir? } & Haftada birkaç kere & 0,23 & 0,42 & 0,35 & \multirow{4}{*}{0,142} & 0,19 \\
\hline & Ayda birkaç kere & 0,25 & 0,45 & 0,30 & & 0,55 \\
\hline & Yilda birkaç kere & 0,34 & 0,41 & 0,25 & & 0,11 \\
\hline & Tüketmem & 0,18 & 0,63 & 0,19 & & 0,15 \\
\hline \multirow{3}{*}{$\begin{array}{l}\text { Bir Önceki Yıla Göre Balık Eti Tüketim } \\
\text { Miktarınız Değişti mi? }\end{array}$} & Azald 1 & 0,30 & 0,55 & 0,15 & & 0,05 \\
\hline & Değişmedi & 0,25 & 0,46 & 0,29 & 0,399 & 0,89 \\
\hline & Artt1 & 0,12 & 0,50 & 0,38 & & 0,06 \\
\hline & Ambalajlı & 0,13 & 0,67 & 0,20 & & 0,04 \\
\hline & Açık & 0,26 & 0,43 & 0,31 & 0,059 & 0,79 \\
\hline Bal1k Etinı Nasıl Satin Alırsinız? & Dondurulmuş & 0,33 & 0,56 & 0,11 & $* * *$ & 0,02 \\
\hline & Tüketmem & 0,18 & 0,63 & 0,19 & & 0,15 \\
\hline & Firında & 0,28 & 0,40 & 0,32 & & 0,38 \\
\hline & Izgara / Mangal & 0,20 & 0,41 & 0,39 & & 0,19 \\
\hline Balık Etini Nasıl Tüketirsiniz? & Yağda kızartma & 0,28 & 0,49 & 0,23 & $\begin{array}{l}0,023 \\
* *\end{array}$ & 0,24 \\
\hline & Buğulama & 0,18 & 0,69 & 0,13 & & 0,04 \\
\hline & Tüketmem & 0,18 & 0,63 & 0,19 & & 0,15 \\
\hline & Lokanta & 0,13 & 0,60 & 0,28 & & 0,12 \\
\hline tini Ey dısında Tüketir misi & Yemekhane & 0,38 & 0,31 & 0,31 & 0,088 & 0,03 \\
\hline Balık Etını Ev dişında I uketır misınız? & Piknik & 0,25 & 0,37 & 0,38 & $* * *$ & 0,21 \\
\hline & Ev dişı tüketmem & 0,26 & 0,49 & 0,25 & & 0,64 \\
\hline & Kesinlikle etkisiz & 0,22 & 0,55 & 0,23 & & 0,06 \\
\hline & Az etkili & 0,00 & 0,50 & 0,50 & & 0,01 \\
\hline Balık Etinin Sağlikli ve Dengeli & Orta & 0,41 & 0,35 & 0,24 & 0,521 & 0,04 \\
\hline Beslenmedek1 Unem Duzey1 Nedir? & Etkili & 0,28 & 0,42 & 0,30 & & 0,38 \\
\hline & Kesinlikle etkili & 0,22 & 0,50 & 0,28 & & 0,51 \\
\hline Balık Etini Yeterli Miktarda Tükettiğinizi & Evet & 0,25 & 0,39 & 0,36 & 0,001 & 0,47 \\
\hline Düşünüyor musunuz? & Hayır & 0,24 & 0,55 & 0,21 & $*$ & 0,53 \\
\hline & Eve yakın olması & 0,38 & 0,50 & 0,13 & & 0,02 \\
\hline & Arkadaş / Dost tavsiyesi & 0,23 & 0,42 & 0,35 & & 0,22 \\
\hline $\begin{array}{l}\text { Balık Etını Satın Alma Y erınızı Belırleyen } \\
\text { Faktör Nedir? }\end{array}$ & $\begin{array}{l}\text { Alışkanlık / Sürekli alım } \\
\text { yeri }\end{array}$ & 0,26 & 0,44 & 0,29 & 0,140 & 0,61 \\
\hline & Tüketmem & 0,18 & 0,63 & 0,19 & & 0,15 \\
\hline & $\begin{array}{l}\text { Kesinlikle } \\
\text { güvenmiyorum }\end{array}$ & 0,33 & 0,48 & 0,20 & & 0,10 \\
\hline Et Satış Noktalarına Güven Düzeyiniz & Güvenim az & 0,35 & 0,51 & 0,14 & 0,010 & 0,24 \\
\hline Nedir? & Orta & 0,19 & 0,49 & 0,31 & $*$ & 0,28 \\
\hline & Güveniyorum & 0,20 & 0,43 & 0,37 & & 0,34 \\
\hline & Kesinlikle güveniyorum & 0,20 & 0,40 & 0,40 & & 0,04 \\
\hline
\end{tabular}


Çizelge 5. (devam) Gelir Gruplarının Oransal Verileri ve Anlamlı1ık Düzeyleri

\begin{tabular}{|c|c|c|c|c|c|c|}
\hline \multirow[b]{2}{*}{ Sorular } & \multirow[b]{2}{*}{ Seçenekler } & \multicolumn{3}{|c|}{ Gelir Grupları } & \multirow[b]{2}{*}{$\mathrm{p}$} & \multirow[b]{2}{*}{$\begin{array}{l}\text { Örneklem } \\
\text { Oranı }(\%)\end{array}$} \\
\hline & & $\begin{array}{l}\text { Alt Gelir } \\
\text { Grubu }\end{array}$ & $\begin{array}{c}\text { Ort.Gelir } \\
\text { Grubu }\end{array}$ & $\begin{array}{c}\text { Yüksek } \\
\text { Gelir Grubu }\end{array}$ & & \\
\hline \multirow{5}{*}{$\begin{array}{l}\text { Balık Etinin Satış Kontrolü Sizce Yapılıyor } \\
\text { mu? }\end{array}$} & Kesinlikle yapılmıyor & 0,39 & 0,40 & 0,21 & \multirow{5}{*}{$\begin{array}{l}0,002 \\
*\end{array}$} & 0,20 \\
\hline & Az yapiliyor & 0,27 & 0,48 & 0,25 & & 0,27 \\
\hline & Orta & 0,14 & 0,60 & 0,26 & & 0,27 \\
\hline & Yapılıyor & 0,22 & 0,40 & 0,38 & & 0,23 \\
\hline & Kesinlikle yapılıyor & 0,27 & 0,28 & 0,45 & & 0,03 \\
\hline \multirow{2}{*}{$\begin{array}{l}\text { Et Tüketmenize Engel Olan Bir } \\
\text { Hastalığınız Var mı? }\end{array}$} & Evet & 0,28 & 0,45 & 0,27 & \multirow{2}{*}{0,557} & 0,34 \\
\hline & Hayır & 0,23 & 0,48 & 0,29 & & 0,66 \\
\hline \multirow{4}{*}{ Balık Eti İle Birlikte Ne Yersiniz? } & Salata/Yeşillik & 0,25 & 0,44 & 0,30 & \multirow{4}{*}{$\begin{array}{l}0,085 \\
* * *\end{array}$} & 0,83 \\
\hline & Yoğurt/Cacık & 0,00 & 0,50 & 0,50 & & 0,01 \\
\hline & Sebze & 0,60 & 0,20 & 0,20 & & 0,01 \\
\hline & Tüketmem & 0,19 & 0,63 & 0,19 & & 0,15 \\
\hline \multirow{6}{*}{ Balık Eti İle Birlikte Ne İçersiniz? } & Alkollü içecek & 0,16 & 0,24 & 0,60 & \multirow{6}{*}{$\begin{array}{l}0,000 \\
*\end{array}$} & 0,07 \\
\hline & Gazlı içecek & 0,29 & 0,48 & 0,23 & & 0,42 \\
\hline & Ayran & 0,09 & 0,82 & 0,09 & & 0,03 \\
\hline & $\mathrm{Su}$ & 0,27 & 0,39 & 0,34 & & 0,31 \\
\hline & Şalgam & 0,00 & 0,43 & 0,57 & & 0,02 \\
\hline & Tüketmem & 0,18 & 0,63 & 0,19 & & 0,15 \\
\hline \multirow{9}{*}{ Hangi Balık Türünü Tüketirsiniz? } & Hamsi & 0,31 & 0,46 & 0,23 & \multirow{9}{*}{$\begin{array}{l}0,067 \\
* * *\end{array}$} & 0,26 \\
\hline & Levrek & 0,24 & 0,34 & 0,42 & & 0,10 \\
\hline & Çipura & 0,11 & 0,37 & 0,53 & & 0,05 \\
\hline & Alabalık & 0,30 & 0,41 & 0,28 & & 0,26 \\
\hline & Palamut & 0,15 & 0,55 & 0,30 & & 0,10 \\
\hline & Somon & 0,22 & 0,43 & 0,35 & & 0,06 \\
\hline & İstavrit & 0,25 & 0,50 & 0,25 & & 0,01 \\
\hline & Sazan & 0,00 & 1,00 & 0,00 & & 0,01 \\
\hline & Tüketmem & 0,18 & 0,63 & 0,19 & & 0,15 \\
\hline
\end{tabular}

$0,01 *, 0,05 * *, 0,10 * * *$ önem düzeylerine göre değerlendirilmiştir.

Balık Eti Tüketiminde Çoklu Regresyon Modeli

Çalışmada balık eti tüketimine etki eden faktörleri ortaya koymak amaciyla çoklu doğrusal regresyon modeli kullanılmıştır. Model ile amaçlanan balık eti tüketenlerin, tüketim miktarlarına etki eden faktörleri ve bu faktörlerin balık eti tüketim miktarını ne derecede etkilediğini ortaya koymak olmuştur. Modelde koşulan bağımlı değişken bireyin balık eti tüketim miktarı olurken; bağımsız değişkenler Medeni durum ( $\beta 1)$, Hane halkı sayısı $(\beta 2)$, Bireyin geliri $(\beta 3)$, Balık eti fiyatı $(\beta 4)$, Dana eti fiyatı $(\beta 5)$ olarak tanımlanmıştır.
Anova tablosunda sig. değeri. 0,000 bulunmuştur. Bu durum bireyin balık eti tüketim miktarının bağımsız değişkenlerle açıklandığ $\breve{g}_{1}$ modelin istatistiksel olarak anlamlı olduğunu göstermektedir. Modelde $\mathrm{R}^{2}$ değeri 0,60 bulunmuştur. $\mathrm{Bu}$ sonuç, bireyin balık eti tüketim miktarındaki (bağımlı değişken) \%60'lık değişimin modele dahil edilen bağımsız değişkenler tarafından açıklanmakta olduğunu göstermektedir (Çizelge 7).Bireyin balık eti talebi için fiyat esnekliği -1,00, gelir esnekliği ise 0,57 olarak hesaplanmış ve istatistiksel olarak anlamlı bulunmuştur. (Çizelge 7).

Çizelge 6. Önceki Çalışmalarda Tespit Edilen Talebin Gelir ve Fiyat Esneklikleri

\begin{tabular}{lclcc}
\hline \multirow{2}{*}{ Yazar } & \multirow{2}{*}{ Y11 } & \multicolumn{2}{c}{$\begin{array}{c}\text { Araştırma } \\
\text { Bölgesi }\end{array}$} & \multicolumn{2}{c}{ Balık Eti Talebi } \\
\cline { 3 - 5 } Selvanathan ve ark. & 2015 & Suudi Arabistan & 1,19 & $-0,22$ \\
\hline Motallebi ve Pendell & 2013 & İran & 1,30 & $-1,72$ \\
\hline Basarir & 2013 & UAE & 0,97 & $-0,98$ \\
\hline Dhraief, Oueslati ve Dhehibi & 2013 & Tunus & 0,61 & $-1,19$ \\
\hline Alboghdady ve Alashry & 2010 & Misır & 1,35 & $-0,79$ \\
\hline Armağan ve Akbay & 2008 & Türkiye & 0,59 & $-0,43$ \\
\hline Akbay ve ark. & 2008 & Türkiye & 0,11 & $-0,20$ \\
\hline Hatırlı ve ark. & 2007 & Isparta & & $-0,51$ \\
\hline Ezedinma, Kormuwa ve Chianu & 2006 & Nijerya & 0,63 & $-1,30$ \\
\hline Jabarin & 2005 & Ürdün & 0,13 & $-0,65$ \\
\hline Şengül & 2004 & Türkiye & 0,76 & $-0,77$ \\
\hline Akçay & 1999 & Tokat & 0,16 & $-0,18$ \\
\hline Paksoy & 1998 & Kahramanmaraş & 0,97 & \\
\hline
\end{tabular}


Modelin talep fonksiyonu,

$$
Y=0,288+\left(0,065 * \beta_{1}\right)+\left(-0,135 * \beta_{2}\right)+\left(0,008 * \beta_{3}\right)+\left(-0,014 * \beta_{4}\right)+\left(0,007 * \beta_{5}\right)+\varepsilon
$$

$\beta_{1}$ : Medeni durumun evli olması, bireyin aylık balık eti tüketim miktarını 0,065 kg artıracaktır (Çizelge 7).

$\beta_{4}$ : Balık eti fiyatında 1 TL'lik artış, bireyin aylık balık eti tüketim miktarını 0,014 kg azaltacaktır (Çizelge 7).

$\beta_{2}$ : Hanehalkı birey sayısında 1 kişilik artış, bireyin aylık balık eti tüketim miktarını 0,135 kg azaltacaktır (Çizelge 7). $\beta_{3}$ : Bireyin aylık gelirinde 1 TL'lik artış, bireyin aylık $\beta_{5}$ : Dana eti fiyatında 1 TL'lik artış, bireyin aylık balık eti tüketim miktarını 0,007 kg artıracaktır. (Çizelge 7). balık eti tüketim miktarını 0,008 kg artıracaktır (Çizelge 7).

Çizelge 7. Balık Eti Talep Modelinin Tahmini Sonuçları

\begin{tabular}{|c|c|c|c|c|c|c|c|c|c|c|c|}
\hline \multirow{2}{*}{$\begin{array}{c}\text { Ürün } \\
\text { Adı }\end{array}$} & \multirow{2}{*}{$\beta 0$} & \multirow{2}{*}{$\beta 1$} & \multirow{2}{*}{$\beta 2$} & \multirow{2}{*}{$\beta 3$} & \multirow{2}{*}{$\beta 4$} & \multirow{2}{*}{$\beta 5$} & \multirow{2}{*}{$\mathbf{R}^{2}$} & \multirow{2}{*}{$\begin{array}{c}\text { Gelir } \\
\text { Esn. }\end{array}$} & \multirow{2}{*}{$\begin{array}{c}\text { Fiyat } \\
\text { Esn. }\end{array}$} & \multicolumn{2}{|c|}{ Anova } \\
\hline & & & & & & & & & & $\mathbf{F}$ & Sig. \\
\hline Balık Eti & 0,288 & 0,065 & $-0,135$ & 0,008 & $-0,014$ & 0,007 & 0,60 & 0,57 & $-1,00$ & 29,942 & 0,000 \\
\hline Sig. & $\begin{array}{c}0,027 \\
* *\end{array}$ & $\begin{array}{c}0,063 \\
* * *\end{array}$ & $\begin{array}{c}0,000 \\
*\end{array}$ & $\begin{array}{c}0,089 \\
* * *\end{array}$ & $\begin{array}{c}0,040 \\
* *\end{array}$ & $\begin{array}{c}0,035 \\
* *\end{array}$ & & & & & \\
\hline
\end{tabular}

$0,01 *, 0,05^{* *}, 0,10^{* * *}$ önem düzeylerine göre değerlendirilmiştir.

Lojistik Regresyon Modeline Dahil Edilen Bă̆ımlı ve Bağımsız Değişkenler

Çalışmada balık eti tüketimine etki eden faktörleri ortaya koymak amaciyla lojistik regresyon modeli kullanılmıştır. Tüketenlerin ' 1 ', tüketmeyenlerin ' 0 ' olarak kodlandığı modelde bağımlı değişken balık eti tüketim durumudur. Model de kullanılan tüm bağımsız değişkenler kukla (dummy) değişkenler haline dönüştürülerek modele dahil edilmiştir. Kukla değişkenler regresyon modellerinde nitel değişkenlere yer verebilmek için kullanılmaktadır. Hep ya da hiç, var ya da yok, tüketen ya da tüketmeyen değeri alan kavramlar kukla değişkenler vasıtasıyla ekonometrik modellere dahil edilirler. Bu kuklalar temsil ettikleri gruplar için '"1", diğerleri için ' 0 " değerlerini alan değişkenlerdir. Modelde bir kukla değişken, dışarıda bırakılarak diğerleri modele dahil edilmiş ve dişarıda bırakılan değişkene göre diğer kuklalar yorumlanmıştır.

Çizelge 8. Modelde Kullanılan Değişkenler ve İstatistiki Veriler

\begin{tabular}{|c|c|c|c|c|c|c|}
\hline Bağımlı Değişken & & Açılkama & & & Sayı & $\%$ \\
\hline \multirow{2}{*}{ Balık Eti Tüketme Durumu } & & Tüketen(1) & & & 325 & 84,6 \\
\hline & & Tüketmeyen $(0)$ & & & 59 & 15,4 \\
\hline Bağımsız Değișkenler & Kukla Değişkenler & Açıklama & & & Sayı & $\%$ \\
\hline \multirow{2}{*}{ Cinsiyet } & Cinsiyet(0) & Bayan & $: 1 /$ & Diğger : 0 & 210 & 54,7 \\
\hline & Cinsiyet(1) & Erkek & $: 1 /$ & Diğger : 0 & 174 & 45,3 \\
\hline \multirow{2}{*}{ Medeni Durum } & Medeni Durum(0) & Bekar & $: 1 /$ & Diğer : 0 & 95 & 24,7 \\
\hline & Medeni Durum(1) & Evli & $: 1 /$ & Diğer : 0 & 289 & 75,3 \\
\hline \multirow{3}{*}{ Eğitim } & Eğitim(1) & İlköğretim & $: 1 /$ & Diğer : 0 & 77 & 20,1 \\
\hline & Eğitim(2) & Ortaöğretim & $: 1 /$ & Diğer : 0 & 110 & 28,6 \\
\hline & Eğitim(3) & Yükseköğretim & $: 1 /$ & Diğer : 0 & 197 & 51,3 \\
\hline \multirow{3}{*}{ Gelir } & Gelir(1) & $(\leq 1500 \mathrm{TL})$ & $: 1 /$ & Diğger : 0 & 95 & 24,7 \\
\hline & Gelir(2) & (1501-2999 TL) & $: 1 /$ & Diğer : 0 & 180 & 46,9 \\
\hline & Gelir(3) & (>2999 TL) & $: 1 /$ & Diğer : 0 & 109 & 28,4 \\
\hline \multirow{3}{*}{ Yaş } & Yaş(1) & $\leq 30$ & $: 1 /$ & Diğger : 0 & 129 & 33,6 \\
\hline & Yaş(2) & $31-45$ & $: 1 /$ & Diğer : 0 & 147 & 38,3 \\
\hline & Yaş(3) & $\geq 46$ & $: 1 /$ & Diğer : 0 & 108 & 28,1 \\
\hline \multirow{3}{*}{ Hanehalk1 } & Hanehalkı(1) & $\leq 3$ & $: 1 /$ & Diğer : 0 & 226 & 58,9 \\
\hline & Hanehalkı(2) & $4-5$ & $: 1 /$ & Diğer : 0 & 140 & 36,5 \\
\hline & Hanehalkı(3) & $\geq 6$ & $: 1 /$ & Diğger : 0 & 18 & 4,6 \\
\hline \multirow{2}{*}{ Et Hastalığı } & Ethastalığ $1(0)$ & Yok & $: 1 /$ & Diğger : 0 & 252 & 65,6 \\
\hline & Ethastalığg(1) & Var & $: 1 /$ & Diğer : 0 & 132 & 34,4 \\
\hline
\end{tabular}


Ballk Eti Tüketimi Lojistik Regresyon Modeli

Modelde koşulan 11 bağımsız değişkenden 6 tanesi istatistiksel olarak önemli bulunmuştur. Bunlar Cinsiyet1, MedeniDurum1, Eğitim1, Gelir1 ve Hanehalkı2 değişkenleridir (Çizelge 9).

Modelin tahmini sonuçlarına göre;

Erkeklerin balık eti tüketme olasılığı kadınlara göre 5,06 kat daha fazladır (Çizelge 9). Medeni durumu evli olanlar, bekarlara göre 2,52 kat daha fazla balık eti tüketme olasılığı mevcuttur (Çizelge 9). Yükseköğretim grubunda olanlar, ilköğretim grubunda olanlara göre 2,13 kat daha fazla balık eti tüketme olasılığı mevcuttur (Çizelge 9). Akbay ve ark. (2008) çalışmalarında, genel olarak eğitim seviyesi arttıkça balık eti tüketiminin daha fazla arttığını belirtmişlerdir. Nalinci (2013) çalışmasında, eğitim durumu yükseldikçe balık eti tüketiminin arttığını tespit etmiştir.Yüksek gelir grubunda (>2999 TL) olanlar, alt gelir grubuna $(\leq 1500$ TL) göre 2,99 kat daha fazla balık eti tüketme olasılığ 1 mevcuttur (Çizelge 9). Adıgüzel ve ark. (2009) Tokat Almus'ta yaptıkları çalışmalarında, aile geliri ile balık tüketim miktarı arasında ters yönlü bir ilişki olduğunu tespit etmişlerdir.Hane halkı sayısı 2. grupta (4-5 kişi) yer alan bireyler, 3. grupta olanlara ( $\geq 6$ kişi) göre 2,70 kat daha fazla balık eti tüketme olasılığ 1 mevcuttur (Çizelge 9).

Çizelge 9. Lojistik Regresyon Modeli /Balık Eti

Bağımlı Değişken (Balık eti tüketen :1 / tüketmeyen:0)

\begin{tabular}{|c|c|c|c|c|}
\hline Değişkenler & Katsayı & $\begin{array}{l}\text { Standart } \\
\text { Hata }\end{array}$ & $\begin{array}{l}\text { Önem } \\
\text { Derecesi }\end{array}$ & Odds Oranı \\
\hline Sabit Terim & 0,613 & 0,614 & 0,319 & 1,845 \\
\hline Cinsiyet1 & 1,621 & 0,358 & $0,000 *$ & 5,060 \\
\hline Medeni Durum1 & 0,925 & 0,374 & $0,014 * *$ & 2,521 \\
\hline Eğitim1 & $-0,754$ & 0,408 & $0,064 * * *$ & 0,470 \\
\hline Eğitim2 & $-0,446$ & 0,386 & 0,248 & 0,640 \\
\hline Gelir1 & $-1,095$ & 0,437 & $0,012 * *$ & 0,334 \\
\hline Gelir2 & $-0,432$ & 0,404 & 0,285 & 0,649 \\
\hline Yaş1 & 0,576 & 0,498 & 0,248 & 1,779 \\
\hline Yaş2 & $-0,043$ & 0,444 & 0,923 & 0,958 \\
\hline Hanehalk11 & 0,745 & 0,824 & 0,366 & 2,107 \\
\hline Hanehalk12 & 0,994 & 0,378 & $0,009 *$ & 2,701 \\
\hline EtHastalığ 10 & 0,254 & 0,390 & 0,515 & 1,289 \\
\hline
\end{tabular}

\section{SONUÇ ve ÖNERÍLER}

Kahramanmaraș kent merkezinde tüketicilerin balık eti tüketim alışkanlıklarını ve tüketim miktarlarını etkileyen faktörler ile bunlara ilişkin tutum ve davranışların belirlenmesi amacıyla bu çalışma yapılmıştır. Çalışmada anket yapılan tüketicilerin $\% 54,7$ 'si erkek ve \%75,3'ü ise evlidir. Aylık ortalama hanehalkı geliri $2.436,41$ TL ve ortalama gida harcaması ise $567,76 \mathrm{TL}$ olarak hesaplanmıştır. Hanehalkı geliri içinde toplam gıda harcamalarının oranı ise $\% 29$ olarak bulunmuştur.

Tüketicilerin \%84,6'sının balık eti tükettiği ve bireyin ortalama balık eti tüketim miktarı ise 0,344 $\mathrm{kg} / \mathrm{ay}$ olduğu tespit edilmiştir. Gruplar arası en yüksek tüketim yükseköğretim mezunları $(\% 54)$ ve orta gelir grubu (\%44) olarak tespit edilmiştir. Tüketiciler vücut kitle endekslerine göre risk gruplarına ayrılmış ve ankete katılanların genel ortalamasının $(2,61$ likert ortalama) fazla kilolu olduğu tespit edilmiștir.

Balık etini erkekler $(\% 60)$ kadınlardan $(\% 40)$ daha fazla tercih etmiştir. Çalışmada vücut kitle endeksi risk gruplarına bakıldığında, fazla kilolu grubunda erkeklerin kadınlardan daha fazla olduğu görülmektedir. Tespit edilen bu sonucu doğrular nitelikte erkeklerin kadınlardan daha fazla balık eti tüketmesi, erkeklerin daha fazla kilolu olması sonucunu doğurduğu düşünülmektedir. Günümüzde aşırı ve dengesiz et tüketiminin başta obezite olmak üzere çeşitli hastalıklara yol açtığı bilinen bir gerçektir. Bu konuda gerek resmi gerekse sivil toplum kuruluşlarının etkin yayın ve eğitim programları ile tüketicileri sağlıklı ve bilinçli beslenmeye yönlendirmeleri gerektiği düşünülmektedir.

Çalışmada eğitim ve gelir seviyesinin yükselmesi bireyin balık etini tüketme olasılığını da belli oranlarda artırdığı tespit edilmiştir. Eğitimin beslenmede bu denli önemli olduğu günümüzde, sağlıklı ve dengeli besleme ile ilgili öğretilerin eğitimin her kademesinde daha fazla yer almasının, gelecek nesiller açısından oldukça önemli olacağı düşünülmektedir.

Bireyin balık eti talebi için fiyat esnekliği $-1,00$ olarak, gelir esnekliği ise 0,57 olarak hesaplanmış ve istatistiksel olarak anlamlı bulunmuştur. Bu sonuca göre bireyin balık eti tüketimi ihtiyaç mallar kategorisine girmiştir. Tüketicinin ihtiyaç mallarına dahil ettiği balık eti fiyatı, yine tüketici tarafından (4,09 likert ortalama) kesinlikle pahalı bulunmuştur. Uzmanlar tarafindan balık eti tüketiminin önemine her platformda vurgu 
yapılmasına rağmen, fiyatların bu denli yüksek olması hem karar alıcıların hem de üreticilerin mevcut stratejilerini yeniden gözden geçirmelerinin tüketiciler açısından faydalı olacağı düşünülmektedir.

Tüketicilerin et satış noktalarına olan güven düzeylerinin likert ortalaması $(2,97)$ orta düzeyde gerçekleşmiştir. Ayrıca yetkili kurumlarca balık satış kontrolünün az yapıldığ ${ }_{1}(2,63)$ düşünülmektedir. Gıda satışında hijyenin son derece önemli olduğu günümüzde firmaların, ürünleri hazırlandığı ve tüketiciye sunduğu mekanlarını AB standartlarına uygun bir şekilde modernize etmelerinin bir zorunluluk olması gerektiği düşünülmektedir. Ayrıca satış elemanlarının rutin olarak sağlık kontrolünden geçirilmeleri de son derece önemlidir. Tespit edilen bu durumların yetkili makamlarca denetimlerinin yapılması ve konuya gereken hassasiyetin gösterilmesi tüketicilerin bir talebi olarak çalışmada yer almıştır.

Balık eti tüketme eğilimi erkeklerde, evli olanlarda, eğitim ve gelir seviyesi yüksek olanlarda daha fazladır. $\mathrm{Bu}$ duruma uygun olarak mevcut pazarlama stratejilerinin geliştirilmesinde yarar görülmektedir. Buna örnek olarak, erkeklerin kadınlardan daha fazla balık eti tüketme eğiliminde olmasına karşılık; evde günlük tüketilecek gıdaları hazırlayan ve özellikle çocukların sağlıklı beslenebilmesinde daha fazla gayretli olan kadınlardır. Firmalarında bu bilinçle hareket ederek öncelikle kadın tüketicilere yönelik pazarlama politikaları üretmelerinin daha faydalı olacağ1 düşünülmektedir. $\mathrm{Bu}$ bağlamda balığın pişirmeye veya tüketimi hazır işlenmiş olarak pazarlanması önerilebilir. Eğitimin sağlıklı beslenme üzerindeki etkisi oldukça fazla olduğu bilinen bir gerçektir. Çalışmada evlilerin daha fazla balık eti tüketme potansiyelinde olduğu tespit edilmiştir. Sektörde faaliyet gösteren firmalarında ürünlerini pazarlarken aile temalı tüketim sloganları vermelerinin daha etkili olacağı düşünülmektedir.

Ülkede ve araştırma alanında kişi başına düşen balık eti tüketim miktarları oldukça düşüktür. $\mathrm{Bu}$ durumun başlıca sebepleri arasında tüketici alım gücünün düşük olmas1, et ve et ürünlerine uygulanan yüksek KDV oranları ve genel olarak balık eti fiyatının yüksek oluşu görülmektedir. Buna karşın sektörde istikrar ortamını sağlayacak politikaların oluşturulmasının, bazı çevreler tarafından piyasada yaratılan spekülasyonların önüne geçilmesinin, et ve et ürünlerine uygulanan $\mathrm{KDV}$ oranlarının makul seviyeye düşürülmesinin, yasak avlama, (patlayıc1, uyuşturucu, karpit vs. ile su ürünleri avcılığı yapılması) kaçak ve bilinçsiz avlanma yöntemlerinin önüne geçilmesinin ve balık piyasasında aracı sayısının azaltılmasinın mevcut durumu düzeltebileceği düşünülmektedir.

Kahramanmaraş’ta kişi başı balık tüketimi Türkiye ortalamasının altındadır. İlin deniz kenarında bulunmaması ve tüketicilerin deniz balıklarından çok hoşlanmamaları sebebiyle bu durum normal olarak görülebilir. Ancak, iç su potansiyeli oldukça yüksek olan bu şehrin insanlarının, iç su balıklarının tüketimine teşvik edilmesi ve bu konuda gerekli tedbirlerin alınması ile tüketim oranlarını nispeten yükseltilebileceği düşünülmektedir.

Araştırma sonuçlarının, balık sektörü için üretimpazarlama-tüketim zincirinin geliştirilmesinde, firmaların pazarlama stratejilerini ve hedef kitlelerini yeniden revize etmelerinde ayrıca katkılar sağlayacağı düşünülmektedir. Sektöründeki karar vericilerin oluşturacağı ve uygulayacağ 1 strateji ve politikaların amacına ulaşabilmesi için, söz konusu piyasanın durumunun çok iyi bilinmesi gerekmektedir. Aksi halde üretim ve pazarlama faaliyetleri gerçekleştirilirken, tüketici taleplerinin göz önünde bulundurulmamas1, büyük kaynak ve zaman ayrılarak uygulanan politikaların amacına ulaşamayacağının bilinmesi gerekmektedir.

\section{KAYNAKLAR}

Adıgüzel F., Civelek O., Sayılı M., Büyükbay O. E., 2009. Tokat İli Almus İlçesinde Ailelerin Balık Tüketim Durumu. GOÜ. Ziraat Fakültesi Dergisi, 2009, 26(2), 35-43.

Akbay, C., 2005. Kahramanmaraş’ta Hanehalklarının Gıda Tüketim Talebi Ekonometrik Analizi. KSÜ Fen ve Mühendislik Dergisi 8(1):114-121.

Akbay, C., Bilgiç A., Miran B., 2008. Türkiye'de Önemli Gıda Ürünlerinin Talep Esneklikleri. Tarım Ekonomisi Dergisi. 14 (2): 55 - 65.

Akçay, Y., 1999 Tokat Merkez İlçede Gıda Harcamaları ve Gıda Ürünleri İçin Gelir-Harcama Esneklikleri Tahmini Üzerine Bir Araştırma (Genişletilmiş Doğrusal Harcama Sistemi Uygulamas1). Gaziosmanpaşa Üniversitesi. Ziraat Fak. Der. Cilt:16 S1.

Alboghdady, M., and M. K. Alashry. 2010. The Demand for Meat in Egypt: An Almost Ideal Estimation. African Journal of Agricultural and Resource Economics 4 (1): 70-81.

Angiş, S., 2004. Gökkuşağı Alabalığı'nda Soğuk Tütsülemenin Bazı Önemli Kimyasal ve Duyusal Özellikler Üzerine Etkisi. Atatürk Üniversitesi, Fen Bilimleri Enstitüsü, Yüksek Lisans Tezi, 36s, Erzurum.

Anonim, 2013. Hayvancılık Sektörü Raporu 2013. http://www.tigem.com.tr (Erişim tarihi : 16/02/2015)

Anonim, 2014

FAO. http://faostat3.fao.org/download/FB/CL/E (Erişim tarihi : 27/07/2015).

Anonim,2014a. Türkiye İstatistik Kurumu). http://www.tuik.gov.tr/PreTablo.do?alt_id=1005. (Erişim tarihi : 13/12/2015

Anonim, 2014.

FAO. http://faostat3.fao.org/download/FB/CL/E (Erişim tarihi : 27/07/2015).

Anonim, 2014b. TÜİK. Türkiye Sağlık Araştırması 2014. (Erişim tarihi : 20/11/2015). 
http://www.tuik.gov.tr/PreHaberBultenleri.do?id=18 854.

Armağan, G. ve Akbay, C. 2008. An Econometric Analysis of Urban Households' Animal Products Consumption in Turkey. Applied Economics. 40(15), 2025-2032.

Basarir, A. 2013. "An Almost Ideal Demand System Analysis of Meat Demand in UAE." Bulgarian Journal of Agricultural Science 19 (1): 32-39.

Beyazbayrak, Z., 2014. Kahramanmaraş İli Merkez İlçede Balık Tüketim Alışkanlıkları. Kahramanmaraş Sütçü İmam Üniversitesi, Fen Bilimleri Enstitüsü, Yüksek Lisans Tezi, 51s.

Cankurt, M., Miran, B., Şahin, A., 2010. Sığır Eti Tercihlerini Etkileyen Faktörlerin Belirlenmesi Üzerine Bir Araştırma: İzmir İli Örneği. Hayvansal Üretim, 51(2):16-22.

Çukadar, M., 2015. Kahramanmaraş İli Kent Merkezinde Helal Gıda Konusunda Tüketici Davranışları. Kahramanmaraş Sütçü İmam Üniversitesi, Fen Bilimleri Enstitüsü, Yüksek Lisans Tezi, 66s.

Dağtekin, M., Ak, O., 2007. Doğu Karadeniz Bölgesinde Su Ürünleri Tüketimi, İhracat ve İthalat Potansiyeli. SÜMAE YUNUS Araştırma Bülteni, 7(3):14-16.

Dhraief, M. Z., M. Oueslati, and B. Dhehibi. 2013. "Income, Education and Age Effects on Meat and Fish Demand in Tunisia." International Journal of Food and Agricultural Economics (IJFAEC) 1 (2): $1-12$.

Ezedinma, C., P. Kormuwa, and J. Chianu. 2006. "Urban Household Demand for Meat and Meat Products in Nigeria: An Almost Ideal Demand System Analysis." In Paper presented at the Farm Management Association of Nigeria Conference, Jos, Nigeria, September 18-21.

Hatırlı A. S ., Öztürk E., Aktaş R. A., 2007. Kırmızı, Tavuk ve Beyaz Et Talebinin Tam Talep Sistemi Yaklaşımıyla Analizi. Süleyman Demirel Üniversitesi, Sosyal Bilimler Enstitüsü Dergisi, 2007/2 (6):211-221.

Jabarin, A.S. 2005. Estimation of meat demand system in Jordan: an almost ideal demand system. International Journal of Consumer Studies 29: 232238.

Meral, Y., Şahin, A., 2013. Tüketicilerin Coğrafi İşaretli Ürün Alg1sı: Gemlik Zeytini Örneği. KSÜ Doğa Bilimleri Dergisi, 16 (4): 16-24.

Miran, B., 2013. Temel İstatistik, Ege Üniversitesi Basımevi, İzmir, 312s.

Motallebi, M., and Pendell, D., 2013. Estimating an Almost Ideal Demand System Model for Meats in Iran. Proceedings of the Agricultural and Applied Economics Association, 2013 Annual Meeting, Washington DC, 2013 August, 4-6.

Nalinci, S., 2013. Amasya İli Merkez İlçedeki Hanehalkının Et Tüketim Alışkanlıkları ve Et
Tüketimini Etkileyen Faktörler. Gaziosmanpaşa Üniversitesi, Fen Bilimleri Enstitüsü, Yüksek Lisans Tezi, 162s.

Olgunoğlu İ. A., Bayhan K. Y., Olgunoğlu P. M., Artar E., Ukav İ., 2014. Adıyaman İlinde Balık Eti Tüketim Alışkanlıklarının Belirlenmesi. Gıda Teknolojileri Elektronik Dergisi, 9 (1):21-25.

Özdamar, K., 1997. Paket Programlar İle İstatistiksel Veri Analizi 1. Kaan Kitabevi, Eskişehir, 649s.

Paksoy, M., 1998. Kahramanmaraş İli Kentsel Alanda Hayvansal Gıda Maddeleri Tüketimi ve GelirHarcama Esneklikleri. Çukurova Üniversitesi, Fen Bilimleri Enstitüsü, Yüksek Lisans Tezi, 53s.

Selvanathan, S., Selvanathan, E.A., Albalawi, S., Hossain, M., 2015. Meat and Fish Consumption Patterns in Saudi Arabia, Applied Economics, 48 (5): 446-460.

Şahin, A., Yıldırım, İ., Deniz, A., 2014. A Comparative Study on Urban and Rural Households Preferences of Fresh Mutton Meat Consumption (a Case Study in Eastern Region of Turkey-Heckman Model), British Food Journal, 116 (12): 1897 -1908.

Şengül, S., 2004. Türkiye'de Gelir Gruplarına Göre Gıda Talebi. ODTÜ Gelişme Dergisi, 31(1): 115148.

Takma, Ç., Atıl, H., Aksakal, V., 2012. Çoklu Doğrusal Regresyon ve Yapay Sinir Ağ1 Modellerinin Laktasyon Süt Verimlerine Uyum Yeteneklerinin Karşılaştırılması. Kafkas Üniversitesi, Veterinerlik Fakültesi Dergisi, 18 (6): 941-944.

Temel, T., 2014. Rize İlinde Hanelerin Balık Tüketimi Üzerine Etkili Olan Faktörlerin Belirlenmesi. Atatürk Üniversitesi Fen Bilimleri Enstitüsü, Yüksek Lisans Tezi, 74s.

Verbeke, W., Vanhonacker, F., Sioen, I., Camp, J.V., De Henauw, S., 2004. Perceived Importance of Sustainability and Ethics Related to Fish: A Consumer Behavior Perspective. Ambio, 36(7): 580585.

Wang, H., Zhigang, C., Mao, T., Yanna, T., Gale, F., 2009. Chinese Consumer Demand for Food Safety Attributes in Milk Products. Food Policy, 33(1), 2736.

Yücel, A., 2001. Et ve Su Ürünleri Teknolojisi. IV. Baskı. Uludağ Üniversitesi, Ziraat Fakültesi, Ders Notları No: 47.

Yüksel, F., Karaton Kuzgun, N., Özer, İ. E., 2011. Tunceli İli Balık Tüketim Alışkanlığının Belirlenmesi. Karadeniz Fen Bilimleri Dergisi, 2(5):28-36. 